\title{
Is Christianity a Hoax? ${ }^{\circledR}$
}

\section{Solving the "Jesus Paradox" through the "Dununu" Principle"}

\author{
Nyasha Mboti, \\ University of Johannesburg, \\ nmboti@uj.ac.za
}

\section{[DRAFT PAPER: DO NOT CIRCULATE, USE OR CITE WITHOUT AUTHOR'S PERMISSION]}

\begin{abstract}
Can a thing be what it is not? Can a thing be where it is not, and not be where it is? Can God not be God? Can God afford to be a dununu? In this article, I unveil the "Jesus Paradox", and try to solve it using a Biblically derived principle. I propose that Christianity is a hoax, because it breaks the "stupidity principle" or the dununu principle. The stupidity principle is the fact that a sovereign God cannot do stupid things. Christianity, though, bears all the marks of a very deep stupidity. Any God who seems to make provision for His own death, or who admits that He once died, seems to me to be a hopelessly stupid God. The Jesus paradox arises because of what seems to be a unique though simple discovery: that there is, in fact, one thing that God cannot do. God cannot afford not to be God. That is, God cannot die. The paradox which traps Jesus is that He needs to die in order to show that He is God, but by dying He forfeits being God. Could Jesus die? Can He die? Can God afford to die? In this theoretical article I draw some provisional notes around the problem. In the end, I solve the Jesus paradox through the dununu principle. Because God cannot die, resurrection and Christianity are in fact irrelevant.
\end{abstract}

Keywords: Christianity; Christ; Jesus; God; Resurrection; Christology; Jesus paradox; dununu; dununu principle; stupidity principle.

\footnotetext{
${ }^{1}$ Shona term for a hopeless fool, or at least a cross between a blockhead and a cretin. To be called a dununu is not just the worst form of disrespect one can endure, but functions to symbolically annihilate the dununu. A dununu is no different to a doornail, a piece of rock, a log or a chitunha (corpse).
} 


\section{Introduction}

Growing up as a young church goer I always (secretly) wondered about Christ's true nature. How, for instance, was this well-known being able to manage to get away with being both fully human and fully God? What happened to His fully human side in the course of resurrection and returning to heaven? Is He still fully human even in heaven? Or did He leave His humanity on earth? What was that all about? The same kind of puerile bafflement would, for some time, overtake me when my pubescent mind considered the conjugal situation of a polygamous King Solomon. How did this wise king get away with having so many wives, lovers and concubines? How did it work? By what wise mechanism? How and where did he find time to also rule a kingdom efficiently? Did he, at night, turn into a supermutating demon? Could the demon be where it was not, and not be where it was?

What fascinated me, in simple terms, was the sheer impossibility of these situations. How can the impossible happen? Under what conditions? When I thought about God in this manner I tended to reduce His situation to mundane vocabularies, as if His situation were mine, and as if He were someone I could bump into on the road, or someone who liked football, cigarettes, toys, games, whiskey or girls. I used to wonder whether He went through all the torments and cravings of puberty that young adolescents go through. If He was both fully man and fully God, how did He (know when to) switch from God mode to human mode? Like cars switching lanes on the freeway? Like train wagons in a shunting yard? Could He be what He was not?

Some time ago, observing Easter festivities at a local Johannesburg church, and listening to a pastor effervescently claim that Christ died on the cross for our sins, the old blasphemy-tinged questions and doubts about impossibility crept back. Though I had heard this Easter-time claim hundreds of times, this time I chose not to let it pass uninterrogated. Can a thing be what it is not and not be what it is? Can God die? Can God who dies still be God? In what sense will He still be God? Can God afford not to be God? I was compelled, once again, to wonder about the true nature of Christ.

My musings today are, of course, a tad more tenacious in comparison with the ones I had as a teenager. For instance, I am no longer intent on just wondering whether Jesus was fully two-in-fully one. I am, rather, intent on asking more fundamental questions about the status of God Himself and Christianity itself. If Christ was fully two-in-fully one (or fully two-in-fully two, or whatever), where does that leave Easter? Where does that leave Christian orthodoxy? That is, I wondered whether Christianity 2 itself might not be based on an untenable idea.

\footnotetext{
${ }^{2}$ Cf. Anderson 2010; Carroll 1987; Chidester 2000; González 1984; Laux 1989; Noll 2000; Schaff \& Schaff 1910.
} 
This article is the result of my summoning a bit of sudden courage to confront old questions in the light of renewed doubts. It does not pretend to be the first, the best, or the last, article to raise these questions. All I intend to do is to test the soundness of this well-worn 2000-year old catenary bridge called Christianity. Do the guardrails of Christian belief continue to hold? What holds them in place? What upsets them?

I have, as the case may be, little or no interest in wading into any of the wellknown squabbles about orthodoxy versus heresy and apostasy that seem to dominate Christology. ${ }^{3}$ Who cares about orthodoxy versus Arianism ${ }^{4}$ - or Gnosticism ${ }^{5}$, Donatism ${ }^{6}$, Pelagianism ${ }^{7}$, Monophysitism ${ }^{8}$, Marcionism ${ }^{9}$, Montanism ${ }^{10}$, or Sabellianism ${ }^{11}$ - when the question about God's relationship with utununu ${ }^{12}$ ought to be real question? Not only are these theological disputes and controversies best left to squabbling experts, but as a whole they are irrelevant to my thesis that God has no business being a fool. Such long-standing questions and disputes, I feel, are sustained largely because they do not take seriously the question of the potential irrelevance of resurrection itself. McGrath (2009: 13) calls heresy "a failed attempt at orthodoxy". I would, however, modify that to say that heresy is a failed attempt at recognising that God is not an idiot.

As this article will attempt to demonstrate, orthodoxy itself masks its own deep basis in heresy. That basis, I shall show, is illustrated by the mechanics of that persistent belief that God once died on a Good Friday in $1^{\text {st }}$ century Judea - a belief which essentially assumes that God is an idiot. Once death on the cross and resurrection are shown to violate the dununu principle, the "theological incorrectness" (Slone 2004) vanishes. That is, there will be little need for Christology anyways. Stupidity, or utununu, as a principle, will be the main building block, derived from Psalms 14: 1, which I will hope to consistently

\footnotetext{
${ }^{3}$ Cf. Clifton 1992; Ehrman 2003; Asad 1986; Edwards 2009; Baker 1972; Fairbairn 2003; Iricinschi \& Zellentin 2008; Kelly 2012; Roach 2005; Roach \& Simpson 2013; Hanson 2005; Lourdaux \& Verhelst 1973; Brooke 1968; Berlinerblau 2001; Waugh \& Diehl 1996; Zito 1983; Moore 1970, 1994, 2000, 2008; Pegg 2008; Berkhout \& Russell 1981; Frassetto 2006, 2007; Laursen 2002; Peters 1980; Hamilton \& Hamilton 1988; Russell, 1963, 1971, 1992; Wakefield \& Evans 1991; Ames 2015; Deane 2010; Christie-Murray 1976; Hunter, Laursen \& Nederman 2005; Sackville 2011; Cohn 2000; Caterina \& Biller 2003; Wood 1993; McGrath 2009;

${ }^{4}$ Cf. Wiles 1996; Barnes \& Williams 1993; Williams 2001; Parvis 2006; Gregg \& Groh 1981; Hanson 2005; Johnson 2005; Gwatkin 1898.

${ }^{5}$ Cf. Filoramo 1990; Wink 1993; Pagels 1978; Faivre 2000; Layton 1981, 1987; Perkins 1980, 1981; Robinson 1988; Wilson 1968; Holroyd 1994; Churton 1987; Rudolph 1983; Hedrick \& Hodgson 1986; Stoyanov 2000; Hoeller 2002;

${ }^{6}$ Cf. Frend 1952.

${ }^{7}$ Cf. Ogliari 2003; Rees 1988a, 1988b; Weaver 1996.

${ }^{8}$ Frend 1972; Luce 1920; Chesnut 1976

${ }^{9}$ Cf. Blackman 1978; Loos 1974

${ }^{10}$ Cf. Tabbernee 1997, 2007.

${ }^{11}$ Cf. Kelly 1978; Gwatkin 1912.

${ }^{12}$ Noun for dununu.
} 
use to counter and expose the main, debilitating Christian heresy of Easter. A dununu, as we will see, is an annihilated being. That is, a dununu is no different to a doornail, a piece of rock, a log or a chitunha (corpse). God cannot be that.

Christological controversies about the resurrection tend to focus largely on whether Jesus rose from the dead, ${ }^{13}$ or how he did it. ${ }^{14}$ Is there a historical Jesus? ${ }^{15}$ What is the meaning of that piece of real estate, the empty tomb? ${ }^{16}$ However, the real debate - to my mind -lies elsewhere. I ask: Could God die? Could a thing be what it is not, and not be what it is? Could God afford to die? Could God sanction not being God? Is being God compatible with being stupid? I am going to insist that until we address these questions satisfactorily, it is pointless to talk of heresies and apostasies. For there to be Christological heresy and apostasy, there has to be resurrection and Christianity first. The dununu principle and the questions that I ask, however, are not dependent on either resurrection or Christianity. Indeed, my thesis is that Christianity violates its own terms and conditions, and therefore is a hoax. That is, it can be shown that resurrection is more or less a waste of time. If there is warrant to my approach, there will be no more need to burden the conscience with the opinions of Ecumenical Councils of days past, with Easter, and even with large parts of Christian belief. Perhaps the Bible itself can even be safely abolished, retired to the bookshelf along with other much-loved but rarely read fictional classics.

\section{Hoax or Not?}

So, is Christianity a hoax? I intend to use a set of building blocks and to offer a set of reasons for conditionally reaching such a conclusion, all of them drawn from the Bible. My main hypothesis will be that Jesus either faked His death, or is an Impostor. The approach I shall use makes it harder to reach any other provisional conclusion. This is not to say I am right. Indeed, I am less interested in being "right" than in being consistent. I hope to reach conclusions consistent with the data and the questions that I shall provide. My principal intention is simply to use a different approach to test and make sense of an admittedly old question. The approach is premised in the form of a question: can a thing be where it is not, and not be where it is?

\footnotetext{
13 cf. Strobel 2010; O’ Collins 1987, 1993; Wilkins \& Moreland 1995; Baggett 2009; Wright 2003; Bruce 1960; Avis 1993; Moreland 1987; Aus 2008; Anderson 2006; Price \& Lowder 2005; Allison 1985, 2005; Barker 1996; Geisler 1992; Beasley-Murray 1964, 2000; ; Kreeft \& Tacelli 1994; Binz 1989; Tenney 1963; Blomberg 1987; Hoover 1976; Crossan 1991; Davis, Kendall, \& O’Collins 1997; Habermas 2004.

${ }^{14}$ Lüdemann 1996; Gunter 1999; Craig 1981, 1988, 1989, 1994; Craig \& Meister 2009; McCane 2003; Geivett \& Habermas 1997; Brown 1973; Bynum 1995; Copan 1998; Grudem 1994; Hodge 1986; Berkhof 1996; Ladd 1975; Wenham 1993; Kreeft 1983; France 1986; Finegan 1992; Habermas, Flew, \& Ankerberg 2005; Licona 2010; McKenna 2004.

${ }^{15}$ Peters, Russell \& Welker 2002; Perry 1993; Scott 2008, 2010; Vermes 2008; Westcott 1902.

${ }^{16}$ Craig 1988; Price \& Lowder 2005; Smith 2010; Waterman 2006.
} 
Christianity inevitably hinges on the doctrine of the Resurrection (Rubin \& Simons 2009; Noble \& Smith 2008; Anderson 2010; Ott 1974; Noll 2000; Pelikan 1971-1989). It is such a central tenet that if you take it away, there is no Christianity. In the Resurrection lies the whole salvific value of the Jesus story (Wright 2003, 2008; Durrwell 2002; Habermas 2003; Leon-Dufour 1974; McDonald 1989; Schlier 2008; Williams 2003). It is God Himself who rises from the dead (Swinburne 2003). The "restoration of Israel" (Levenson 2006) itself seems directly dependent on the resurrection. But could Jesus die? Did Jesus really die? The preliminary form of the problem arises as soon as we consider the contradiction of admitting that Jesus died on the Cross. We are reminded, for instance, that Jesus is immortal, the Alpha and Omega. There is nothing He cannot do. As Pink (1984: 240) argues, "God initiates all things, regulates all things”. Hence when God decomposes, there are grounds to suspect a scam. After all, He is Omnipotent (Wierenga, 1983) ${ }^{17}$. Consider when the "Unsinkable" Titanic sank. Was this not proof that the Titanic may only have been pretending to be unsinkable? Unsinkable things have no business sinking.

It ought to be self-evident that a person who lives forever cannot die. Which brings us to a set of preliminary observations. Either Jesus died, or He did not. Either He did for death, or it did for Him (granted, it was only for two days). Which is which? Either He is God or He is not. Either He lives forever, or He does not. It will seem that, as God, He not only reserves the right to do whatever He wants (Psalm 115:3), but is in fact able to be both and all of these contradictory things and states, all at the same time. He is God after all. He would not be God if there was something He could not become. However, I intend to demonstrate why God cannot be both/and.

Suppose Christians begrudgingly accede to the view that death could have overcome Jesus for some few days. The duration does not matter. It could have been two days, five minutes, or ten seconds. Is this not in itself admission and, perhaps, part proof that death did indeed get the better of Jesus, though only for a short time? And if death tried this act and succeeded once, could it not have cause to claim some measure of power over the Christian God?

Is it even acceptable to imagine that there was a time in the past when one's God was really dead, even for five seconds or for milliseconds? Would that not render Christianity itself fatally flawed and without basis? Or, to come to the other point, did Jesus merely pretend that he was dead - even though we all knew that He does not really die and did not really die? Did the unsinkable Titanic merely pretend to sink, as part of some insurance fraud? But if Jesus did not die, and only staged His death, does this not

\footnotetext{
${ }^{17}$ An Omnipotent being, according to Wierenga, "must be able to actualize any state of affairs that it is possible that the being strongly actualize”.
} 
place the very basis of Christianity itself in doubt, in imposture? Which is it to be? Surely, one cannot eat their cake and still have it.

Christians maintain that God died on the cross. This would be sound claim if it were not so patently absurd. That is, it sounds deeply blasphemous and heretical. Indeed, such a claim is the closest one can come to endorsing the infamous Nietzschean declaration of God's death in The Gay Science (1973) and Thus Spake Zarathustra. The claim that God once died on the cross would seem to constitute a contradiction every single time it comes from the mouth of a Christian.

How can a believer seriously admit the possibility of their own God being dead, even if such a death were only for two days or for a few seconds, and even if this were only being dead in preparation for "coming back" from the dead and triumphing over death itself? Does seem appropriate, for instance, to imagine that Jesus' telomeres shorten as those of other human beings, or that his body cells undergo apoptosis, as if He were going to die from old age or senescence? Point is: it seems a contradiction to declare God dead. Surely, an immortal ought not to die. God cannot die, unless one were only pretending to be "God". God in quotation marks is not God. As we will see, God who claims to have died is lying through his teeth, and God who lies is not God and does not deserve to be God. He is a waste of divinity.

In Christian theology, one of Jesus' main attributes is that He is, of course, absolutely immortal. ${ }^{18} \mathrm{He}$ is invulnerable to death. That is, being the Son of God, He cannot die by any cause whatsoever. As the apostle Peter proclaimed "You are the Christ, the Son of the living God." Peter does not say "You are the... Son of the dying God. That just sounds ridiculous. And yet Christians at Easter clamour around the death and resurrection of God.

God, by dint of being Himself, has no beginning or end. Immortality, of course, is another word for eternal life: the ability to always be alive. That is, by definition, an immortal person has an unending life. It is not known if humans - or, for that matter, anyone else who is not God - can be immortal. At least, no human being has ever succeeded at always being alive, which is not for lack of trying, as alchemists, mind-

${ }^{18}$ Cf. Anderson 2010; Chidester 2000; González 1984; Noll 2000. 
uploaders, ${ }^{19}$ cryonicists $^{20}$, AI, ${ }^{21}$ biotechnologists and bioengineers, ${ }^{22}$ immortality chasers,${ }^{23}$ posthumanists ${ }^{24}$ and transhumanists ${ }^{25}$ will tell you. It seems fair, then, to state that human beings by nature cannot live forever.

The ultimate question we return to is: can Jesus die, or can He not? It does not seem as if he has the freedom to do both, for that would amount to a ghastly contradiction. The only option out of this conundrum, would have been for him to fake his death. After all, a biologically dead person cannot come back to biological life. It stands to reason that, were a biological person to die and then "resurrect", such a person would technically be a completely new being altogether. A person cannot die and return as the pre-mortem being. Any such being who achieves the feat of "coming back" to the same and previous life that they had - the life that by dying they had seemed to completely forfeit and exit -would no longer be the person who died. Any returning-to-life being would have to be someone who never completely died in the first place. Perhaps they were only stunned, or in a comma, or only a certain percentage "dead".

Basically, it seems biologically impossible to return from the dead if one were really dead. Beings that are really dead stay dead. It appears rather doubtful that a person that is " $100 \%$ dead" (say, a decomposing corpse), as it were, may "come back" to their previous pre-mortem, pre-corpse life which they had previously completely forfeited. The one who "comes back" to life from being 100\% dead, from one point of view, may only be classified a mint being. We know from zombie movies that the "undead" are not only

${ }^{19}$ Cf. Hanson 1994; Bamford 2012; Blackford \& Broderick 2014; Bostrom 2003a;

${ }^{20}$ Cf. Fahy et al. 2004; Fahy, Saur \& Williams 1990; Doyle 2012; Best 2008; Merkle 1992.

${ }^{21}$ Cf. Kurzweil 2000, 2013; Moravec 1990, 2000; Barrat 2013; Nourbakhsh 2013; Geraci 2010; Levy 2008; Bostrom 2014; Gordijn \& Chadwick 2009; Chorost 2011; Paul \& Cox 1996; Drexler 1986;

${ }^{22}$ Cf. Agar 2004, 2010, 2013; Naam 2005; Hall 2003; Harris 2007; deGrey \& Rae 2007; Garreau 2006; Alexander 2003; Andrews 2001; Savulescu \& Bostrom 2009; Savulescu, ter Meulen, \& Kahane 2011; KingTak 2009; Parens 2006, 1998; Baillie \& Casey 2004; Pence 2012; Lo 2012; Bateman et al. 2015; Fröding 2013; Eilers, Gruber \& Rehmann-Sutter 2014; Mehlman 2009; Sharon 2013; Green 2008; Moore 2008; Hughes 2004; Blackford 2013; Hauskeller 2013; Shuldrick \& Mykitiuk 2005; Bostrom 2003b; Julian \& Bostrom 2009; Buchanan 2011a, 2011b; Cabrera 2015; Sandel 2009; Hyde \& Herrick 2013; Cole-Turner 2001; Mercer \& Maher 2014; Kass 2004; Rothman \& Rothman 2003; Magnus, Caplan \& McGee 2002; Stock 2003;

${ }^{23}$ Hall 2003; Bova 2000; Hulsroj 2015; Seidel 2010; Olshansky \& Carnes 2001; Shostak 2002; Mitchell, Orr \& Salladay 2004; Deech \& Smajdor 2008; Lo 2012; Tipler 1994; Ettinger 1964, 1972; Weiner 2001;

${ }^{24}$ Cf. Fukuyama 2002; Nayar 2014; Bostrom 2005a; Pepperell 2009; Koosed 2014; Allenby \& Sarewitz 2011; Ranisch \& Sorgner 2014; Seidel 2008; Gray 2001; Lake 2013; Fuller 2011; Badmington 2000; Gordijn \& Chadwick 2009; Beard 2000; Benford \& Malartre 2007; Bishop 2010; Cecchetto 2013; Lewis 2001; Chorost 2011; Merrell 2003; Thweatt-Bates 2012; Doyle 2003; Miccoli 2010; Scott 2010;

${ }^{25}$ Cf. More \& Vita-More 2013; Regis 1990; Bostrom 2003b, 2005b, 2005c, 2006, 2014; Mehlman 2012; Mercer \& Trothen 2014; Mercer \& Maher 2014; Kurzweil 2006; Garreau 2006; Waters 2006, 2014; Hayles 1999; Herbrechter 2013; Fereidoun 1989; Dewdney 1998; Hansell \& Grassie 2011; Cole-Turner 2011; White 2015; Wolfe 2010; Ansell-Pearson 1997; Hauskeller, Philbeck \& Carbonell 2015; Benedikter \& Siepmann 2016; Ranisch \& Sorgner 2014; Halberstam \& Livingston 1995; Ettinger 1972; Haughey \& Delio 2014; Lilley 2012; Bishop 2010; Buchanan 2011a; Molloy \& Shakespeare 2012; Chorost 2011; Hyde 2010; 
fictional, but they look a bit decrepit. Coming back from being a corpse does not seem a very smart choice, particularly for God. What does it mean to come back from the dead anyway? Is it a place? A time? A state of affairs? What is, or are, the dead? Where is, or are, the dead? Who are they? Does God have any business being with them? How does God justify being with the dead? How does God justify being dead?

If we accept this premise - that a "completely dead" being cannot possibly rise again as the same previous pre-mortem being - then it may be plausible to argue that God who "completely" died on the cross could not have been resurrected as the same, previous pre-mortem God. He could only be, rather, a mint God: an impostor. An impostor is a person who pretends to be someone else, often in order to deceive. This constitutes fraud. ${ }^{26}$ Is Christianity founded on fraud?

The alternative to the mint God thesis would be to grant that the pre-mortem God did not die at all, but might have remained the same old pre-mortem Jesus the whole time, and only made it to seem as if He had died. This alternative, premised on seeming, appears to resolve itself on the point of pseudocide, or God faking His death, since God or an immortal is always already immune to any kind of death, and cannot absolutely die. Could Christianity be based on a faked death, or pseudocide, a kind of pretend death like Sherlock Holmes's "death" in The Final Problem where he falls to his death only to reappear to Dr. Watson in The Adventure of the Empty House? Or could it all be based on elaborate imposture?

\section{Jesus' Death and Resurrection: A recap}

The Jesus “death" story is worth recapping. On a tempestuous Good Friday, in 1st century Judea - most probably between 30 and 33 A.D. - a certain Jesus of Nazareth was arrested, arraigned before Pilate, found guilty on a slew of trumped up charges, beaten up, made to carry his cross, and crucified by Roman soldiers. His executioners stripped him naked and divided his clothes amongst themselves, and also offered him wine mixed with gall to drink, which he did not want. Some of the soldiers wanted to break his legs (crurifragium), but could not do so when they discovered that he was already dead. Still, they pierced his side with a lance, just so that they could be certain that he had died. Was Jesus already dead or was he merely playing dead? Could he die?

That same Friday, a certain Joseph of Arimathea, assisted by Nicodemus, removes Jesus' corpse from the cross, wraps it up, and buries it in a tomb. The next day the tomb is secured and sealed with a large stone, and a guard posted on the entrance. Come Easter Sunday morning, when Mary Magdalene checks out Jesus' tomb, she is surprised to find it empty. Jesus had risen from the dead.

\footnotetext{
${ }^{26}$ One supposes that it can be granted that the mint Jesus could possibly be similar to the pre-mortem Jesus, but there is no way they can be the same person.
} 
But had he? It seems he had, for forty days later, the disciples look on serenely as Jesus is "lifted up, and a cloud took him out of their sight". He was "gone into heaven", to sit "at the right hand of God". The biggest hole in this story remains: Did God die that Friday in Judea?

\section{But did Jesus die? Could he die?}

Death, to a layman observer, is a rather unpleasant condition when we are no longer alive. It can be supposed that when we are dead we cannot do anything: we cannot breathe, talk, cough, look, laugh, think, go anywhere, do anything, feel anything, or know anything. When we die, all biological functions that sustain life terminate. Proof that we are no longer alive is that we stop breathing, have no pulse, we get deathly pale in the 15120 minutes after death (pallor mortis), blood drains down and settles in the lower portion of the body (livor mortis), we get a little cold (algor mortis) - although, after a while, the temperature of our corpse matches the temperature of the place where it died - we get all stiff (rigor mortis) and, finally, decomposition sets in (i.e. we rot, and in the tropics we start to stink rather quickly). Death, according to Psalms 146:4 and Ezekiel 18:4, is a state of non-existence. Ecclesiastes 9:5 states that the dead know nothing, and are in a state of complete unconsciousness. The term in the Shona language is more evocative: kupera (to get all used up; expired; to be finished). A dead person is finished.

But this is only the beginning of the story of God's death. There has never been agreement on how to determine death. Since a dead person will never tell you that they are dead, you would have to devise a rigorous criterion for independently determining that a person is really dead and not just sleeping, pretending, in a coma, or just stunned. When is a dead being really dead? Is death a single event or a process? Many professionals, such as biologists, physicians, neurologists, bioethicists, politicians, coroners, cryonicists, organ harvesters, philosophers and others seldom agree on how to define death. So even if we assume, as Christians do, that Jesus died on the cross that Good Friday, we would still have a job on our hands in terms of coming round to a unanimous agreement of what constitutes God's death. Was Jesus legally dead, clinically dead, medico-legally dead, spiritually dead, somatically dead, cardio-respiratory-dead, or brain-dead? Or was He all of these overlapped together? Who do we get to ask? Do we consult a physician, a priest, a lawyer, a philosopher, bioethicist, or a Roman soldier? Or should we consult all of them together? What concept of death ought we to use? Do we use the one from the Bible, the Oxford Dictionary, the American Uniform Determination of Death Act (UDDA), or from the Harvard Committee's (1968) ${ }^{27}$ manual? A primary problem with the determination of

\footnotetext{
${ }^{27}$ Harvard Medical School (1968), Ad Hoc Committee of the Harvard Medical School, “A Definition of Irreversible Coma: Report of the Ad Hoc Committee of the Harvard Medical School to Examine the Definition of Brain Death,” Journal of the American Medical Association 205 (6): 337-40.
} 
death, say Crippen \& Whetstine (2007: 202) "is the inability to establish precisely when it transitions from a reversible process to an irreversible event."

There is in fact no single definition of death that is voluntarily accepted everywhere. The definitions of death come already constrained, proscribed and prescribed by medicine, law, political economy, social relations, ethics, politics, power, religion, culture, commerce and so on (Bernat, Culver \& Gert 1981; Youngner, Arnold \& Schapiro 1999; Cranford 1995; DeGrazia 2014; Engelhardt 1975; Gervais 1986; Persson 2002; Thomas 2012; Lizza 2007; Shaw, Truog \& Miller 2011; Miller \& Truog 2010; Veatch 1976; Shaw, Truog \& Miller 2011). Although it is often normatively believed that "a person is dead when a physician says so", there are several competing definitions. Two standard definitions stand out.

The first definition is the classification of death through "cardio-respiratory criteria". The cardio-respiratory criteria is the more "traditional", somatic view where the physician considers death to have occurred when an individual permanently stops breathing and whose heart permanently stops beating. In the cardio-respiratory sense, death can be broadened to mean "the irreversible cessation of the integrated functioning of the organism as a whole" (Bernat, Culver \& Gert 1981). Typically, all the organs of the body "die" from lack of oxygen. In the words of Miller and Truog (2009: 185), "Traditionally the cessation of breathing and heart beat has marked the passage from life to death. Shortly after death was determined, the body became a cold corpse, suitable for burial or cremation”.

What the cardio-respiratory criteria implies is that any layman could probably try to observe the pulse and signs of breathing to tell if a person was dead or alive. For instance, we see this determination of death visually portrayed in many movies: after the commission of some graphic act of violence, the lack of movement of a body, absence of pulse and lack of breathing are all taken to be definite signs that a character is dead and "gone". This conventional definition of death, however, was altered in the second half of the twentieth century due to technological changes that "prompted calls for a new, or at least expanded, definition of death: the development of intensive care medicine, especially the use of mechanical ventilators, and the advent of successful transplantation of vital organs" (Miller \& Truog 2009: 185). This takes us to the second standard definition of death.

The second definition utilises so-called whole brain death (WBD) neurological criteria to determine death (Pallis 1983). In this definition a person "is not dead unless his brain is dead. The time honored criteria of the stoppage of the heart beat and circulation are indicative of death only when they persist long enough for the brain to die" (Sweet 1978). In 1968, the Ad Hoc Committee of the Harvard Medical School to Examine the Definition of Brain Death proposed that death could be determined on the basis of neurological criteria 
(Ad Hoc Committee 1968). That is, patients diagnosed with the cessation of brain function were to be certified legally dead. This is despite the fact that their hearts might still be beating, that they might still be breathing and circulating blood with the aid of mechanical ventilation (Miller \& Truog 2009). In other words, this is a soft or soft-line definition of death. The softness of this definition has polarised opinion. ${ }^{28}$

Neurological criteria have an important function: they make it possible to conveniently harvest the dead person's organs. ${ }^{29}$ Whereas organ transplantation under the cardio-respiratory criteria is difficult because "successful transplantation requires that organs be removed from cadavers shortly after death to avoid organ damage due to loss of oxygen" (Iltis \& Cherry 2010), the neurological definition of death permit the unplugging of life support systems and the removal of body organs fo future re-use (Bernat 2014; Iltis \& Cherry 2010) while the body's circulatory system is still working (Potts, Byrne \& Nilges 2001).

Suppose God's organs were being targeted for harvesting after His crucifixion. This would obviously necessitate a redefinition of death. That is, if Jesus' organs were to be of any use to harvesters, then His death would need to be interpreted in a soft-line ${ }^{30}$ way. He would have to be certified as dead on the basis of a cessation of consciousness activity in His brain, but not in the rest of His body. Did Jesus' consciousness and higher brain ${ }^{31}$ belong with the fully divine or fully human person of the Christ? On what basis could His organs have been harvested?

As noted, this soft method of defining death has, perhaps not surprisingly, polarised opinion. Questions centre on the methods, ${ }^{32}$ efficacy, ${ }^{33}$ justification and ethics ${ }^{34}$ of certifying the death of a still-breathing person dead, unplugging the intensive care system, harvesting the organs of the "dead donor", and the nature and the rules governing the

\footnotetext{
${ }^{28}$ Cf. Sadovnikoff and Wikler 2014; Rady \& Verheijde 2013; Clarke, Remtema \& Swetz 2014; LiPuma \& DeMarco 2014; Bernat 1992, 1998, 2006a, 2006b, 2010, 2014; Halevy \& Brody 1993; Halevy 2001; Pallas 1999; Pernick 1999; Shewmon 2001; Veatch 1975, 1993, 2004; Wijdicks 2002; Potts, Byrne \& Nilges 2001; Sade \& Boan 2014; Collins 2010; Magnus, Wilfond, \& Caplan 2014; Zaner 1988.

${ }^{29}$ It apparently benefits those with a vested interest in harvesting organs - the so-called "Donation after Cardiac Death" (DCD) activists - to have death redefined. Whetstine et al. (2005) argue that “The demand for organs to facilitate transplantation promotes a strong incentive to define clinical death in a manner that most effectively supplies that demand", noting that the concept of death itself has been made more complex by Intensive Care environment, particularly the blurred the distinction between sapient life and prolongation of vital signs.

30 "(I)f the person cannot spontaneously resuscitate (auto-resuscitation), the person is irreversibly dead as a practical matter" (Whetstine et al. 2005).

${ }^{31}$ Cf. DeGrazia 1999; Rich 1997.

32 Cf. Shewmon 1998; Halevy \& Brody 1993; Brody 1999; Halevy 2001; Bernat 1992; McMahan 2006;

${ }^{33}$ Cf. Shewmon 2001;

${ }^{34}$ Cf. Sadovnikoff and Wikler 2014; Truog \& Robinson 2003; Veatch 1975, 1993, 2004; Potts 2001; Rady \& Verheijde 2013; Potts, Byrne \& Nilges 2001; Truog \& Miller 2012.
} 
"dead donation" ${ }_{35}$ - since organ harvesting is typically constrained by the need for speed and by "dead donor" rules. ${ }^{36}$ Is a brain dead being dead enough? ${ }^{37}$ How much brain must be dead? ${ }^{38}$ When is a dead person dead enough? Is brain death equivalent to human death? Is a brain-dead patient a cadaver?

So could Jesus have gone into non-existence and complete unconsciousness? Was he finished? Could he afford to be expired, even briefly? If we are to define Jesus' death medically, we would need to grapple with the problem of distinguishing his death from his life. At what point was Jesus really expired? Was Jesus ever really and totally finished? At what point can we precisely determine that his human-divine life had completely ceased? Can we even precisely determine that his life had completely ceased? What was the nature of the cessation of Jesus' biological functions? When, if at all, did His life finally and completely terminate? We know, from the Roman soldiers deciding not to break his legs that Jesus was probably no longer breathing and had no pulse. We know that, to be sure, they stuck a lance in his side, piercing both heart and lungs, and blood and water gushed out. Surely, no one could survive that? So, perhaps he really was dead.

But there are also grounds for misdiagnosis of death. The Roman soldiers who were present were no coroners or trained medical doctors. Their view could only have been subjective and imprecise. Had the soldiers done CPR and prompt defibrillation on Jesus (instead of busying themselves with despoiling his garments), could they have restarted his breathing and heartbeat? The so-called "Lazarus phenomenon" (Bray 1993), a phenomenon of return of spontaneous circulation (ROSC) after discontinuation of cardiopulmonary resuscitation (CPR) - first reported in 1982 (Linko, Honkavaara \& Salmenperä 1982) - could perhaps have returned God to life? Though the soldiers perforated Jesus' heart and lungs with a lance, Christ's life could have been sustained with a combination of artificial sustenance such as life support devices and artificial pacemakers. There was also the option of a lung or a heart transplant.

Cryonicists prefer a definition of death that calls into question any prior declaration of death, whether using the cardio-respiratory standard or brain death criteria. Cohen (2012), for instance, believes that cryopreserved beings are not dead but, rather, are merely "in a state of deanimation”. Had Jesus been intubated, ventilated and

\footnotetext{
${ }^{35}$ Cf. Sade 2011, 2014; Truog 2008; Truog \& Robinson 2003; Truog \& Miller 2008; Kuramochi 2005; Siminoff, Burant \& Youngner 2004;

${ }^{36}$ Organ donation rules (the dead donor rule [DDR]) stipulate that organs may not be removed prior to death nor may organ procurement cause or hasten death. That is, patients must not be killed by organ retrieval. An organ donor "must be declared to be irreversibly and unequivocally dead and not merely dying before the commencement of organ extraction" (Kuramochi 2005)

${ }^{37}$ Elliott \& Budwany 2014.

${ }^{38}$ Cf. Brody 1999.
} 
deanimated, perhaps He would not have required resurrection at all but merely thawing, or at least what cryonicists call "revival”?

How much expertise, for instance, did the Roman soldiers have in the neo-cortex ${ }^{39}$ of the brain and in states of "brain death" and "biological death" in order to precisely define God as being really dead? Suppose that an end of electrical activity in the brain indicates the end of consciousness. Did the Roman soldiers accurately observe the permanent cessation of electrical activity in God's brain before declaring Him dead? Could they identify the irremediable loss of cognitive function, through noting the death of the cerebral cortex? What if Jesus were merely in coma? What if His nerves only were badly stunned from all the scourging and carrying of the heavy cross on his shoulders? How sure were the soldiers that God, though crucified and "dead", could still not have maintained the ability to sustain blood circulation and respiration and excrete waste? What protocols did they use, other than the lance, for determining brain death or absence of life?

At any rate, it would seem that the medical signs of Jesus death are not enough in themselves as concrete proof of death, for this was not a mere man dying. This was God who was dying. Here, things become complicated, for there is little consensus on how to medically and biologically define Jesus' mortal-but-immortal life. We cannot medically determine Jesus' death, because we cannot medically define his life. ${ }^{40}$ Did death merely mark the end of Jesus' consciousness? Was He - as Scrooge would say of old Marley in Dickens's A Christmas Carol - dead as a doornail, or did He only die in several transient stages, rather than in a single event? Could He instead have only been in an intermediate state between death and resurrection - as in being in the infernum? If Jesus were merely coasting and milling about in an intermediate state - of degrees of half-death and half-life - then perhaps it made sense for Him to "return" from the dead by way of simple reversal of this graduated process, as if He were reversing a bank transaction.

\section{Enter the Ecumenical Councils}

A major Christological dispute that dominated the 4th and 5th centuries of the Christian era concerned whether, and how, Jesus was part of the Godhead. ${ }^{41}$ Debated from the First Council of Nicaea (A.D. 325) (Ayers 2006; Forell 1965; Burn 1925) until the Third Council of Constantinople (A.D. 680), (Davis 1983; Kelly 2009) the thorny question of the Godhead was settled by the creed that Jesus, as the Son of God, was homoousios

\footnotetext{
${ }^{39}$ Puccetti 1988; Bartlett \& Youngner 1988.

${ }^{40}$ Becker 1975.

${ }^{41}$ Cf. Anderson 2010; Ayers 2006; Bellitto 2002; Bokenkotter 2004; Bright 1892; Burn 1925; Carroll 1987; Davis 1983; Denzinger 1957; Edwards 2009; Forell 1965; González 1984; Johnson 2005; Kelly 2009; Kelly 1978, 1981; Laux 1989; L’Huillier 1996; MacMullen 2006; Margull 1966; Martin 1978 (1930); McDonald \& Sanders 2002; Noll 2000; Murphy 1960; Ott 1974; Tanner 1990, 2001.
} 
(of one substance) with the Father (Tanner 1990; Bright 1892; Burn 1925; Ott 1974; Murphy 1960; Noll 2000)

In essence, Jesus was not just similar to God. Instead, his divinity was the same as that of God the Father. That is, Jesus was also God in his own right. Jesus, as God, is sovereign, omniscient, good, just, immutable, eternal, and omnipresent. He boasts every single one of those attributes and excellences that his Father possesses, including - as the case may be -God's invisibility and wrath. He has the character, holiness, infinity, unity, grace, immensity, power, mercy, perfection, and glory of God. That is, when we see Jesus, we have also seen God. We no longer need to see God Himself. This is the way I see and refer to Jesus in this article: as God. At any rate, Jesus was decreed to be the second Person of the Trinity, coequal and coeternal with God.

Interestingly, it was decreed - somewhat confusingly - by the Council of Chalcedon (451A.D.) that Jesus was also fully human. This decree emerged from, and led to, an old question in Christology: how a human nature and a divine nature could have co-existed in the single being of Jesus. The solution was to regard Jesus as some sort of Schrödinger's cat: occupying two contradictory states simultaneously. In Christ are two natures coexisted "without mingling, without change, indivisibly, undividedly, the distinction of the natures nowhere removed on account of the union but rather the uniqueness of each nature being kept and uniting in One Person and One Substance, not divided or separated into two persons, but one and the same Son only begotten God Word, Lord Jesus Christ”. The logic is that Jesus is God incarnate, being both God and man, both fully divine and fully human. The Nicene Creed, in particular, rejected any attempts to diminish either the divinity or the incarnate humanity of Jesus. In any event, an either/or view of Jesus was deemed heresy (Denzinger 1957; Bright 1892; Edwards 2009; L'Huillier 1996; Kelly 1978; Johnson 2005).

Even more confusingly, the human Christ (as Hebrews 7:26 shows) was described as being impeccable, sinless and flawless: he was "holy and without evil". How could he be fully human but still retain impeccability, sinlessness and flawlessness? Surely a human being ought to be imperfect? But, as noted, the Council of Chalcedon declared that there are in fact two natures in the single person of Jesus, one human and the other divine. Each nature, however, retains its own properties (Denzinger 1957; Ott 1974; Tanner 1990; Martin 1978 [1930]); Noll 2000; Johnson 2005)

This so-called hypostatic union, crucially, comes with a disclaimer: we could never understand how it works, even if we tried. It is beyond human understanding. That is, one needs to have faith and belief, since the problem cannot be reasoned about. The problem with this solution is that it appeals to people to understand that they do not need to understand in order to understand. People need to know that they do not need to know in 
order to know. That is, the solution appeals to reason in order to make that the point that reason must not be appealed to. One needs to reason that reason is not needed. It is like asking someone to think that they are incapable of thinking. The appeal to faith, in this sense, seems illogical: it is an appeal to know through not-knowing.

How do the church fathers know what they know anyway? How do they know what they claim cannot be known? How did they come upon this knowledge that the hypostatic union cannot be known by knowing? How does one know through not-knowing? At any rate, faith seems to be a particular kind of commitment, one that is dependent on free will, and hence is predicated on choice. Choice (for instance, whether to go left or right) is predicated on the ability to differentiate left from right. Once differentiation comes into the picture, it seems highly unreasonable to ask reasonable people to reason that they must not reason. That is, reason, knowing and understanding always return via the back door. The hypostatic union thus can and should always be subjected to rational questioning.

Should we not conclude that, because Jesus was always and already coequal and coeternal with God (and the Holy Spirit), even before Creation, then surely he was only pretending to be mortal? There seems to be little doubt about the God-ness of Jesus from the very beginning. Indeed, Jesus has no beginning or end. In other words, he was always already God (the Son) - and therefore immortal and eternal - way before he became "a human being" in Nazareth, for his earthly mission. The famous John 1:1 clinches the argument, stating that the "the Word was God". That is, Christ the Logos was always God from the beginning.

Was Jesus" "birth" and "death" as a human being (the so-called Incarnation: “And the Word became flesh, and dwelt among us") merely staged for maximum effect? It seems so, since one signal feature of the so-called atonement, the Sacrifice of the Cross, would itself not be wholly efficacious were the Christus Victor not totally divine. But then: a divine Christus Victor cannot die. He can only pretend to die. It seems we are going around in circles. How do we break out of it?

During the so-called Transfiguration (Matthew 17:1-9, Mark 9:2-8, and Luke 9:28-36), Jesus "was transfigured before them, and his face shone like the sun, and his clothes became dazzling white." How could this same "transfiguring" being - who also is able to accurately predict his betrayal, trial, scourging and painful death - literally "die" only a week or so after his transfiguration?

If he (and his Father in Heaven) had inside knowledge (they are prescient, after all) of every single thing that was going to happen, and how it would happen, would this not constitute divine "insider trading" of sorts? Would this not then amount to a staged 
spectacle? Why, for instance, did Jesus not have an escape plan? Did he intend to get killed? Was He a doomed Christ?

Perhaps the fully Human Jesus completely died, while the fully Divine Jesus did not? But, then, where was the fully Divine Jesus when the fully Human Jesus was in the throes of death? Did they separate into body and soul? What does this imply for the hypostatic union? It may be that the Divine (as some sort of undying soul?) may have loitered and lollygagged about Judean skyline, waiting to re-enter the limp body (now a mere pocket for the soul?) three days later. Such an interpretation would accord in some respects with what is often termed Cartesian substance dualism, drawn from the thought of René Descartes (1596-1650) - the kind which gave rise to the so-called mind-body problem. Descartes held that there are two kinds of foundation (mind and body), and that the mind, as the seat of consciousness and self-awareness, is a nonphysical, non-spatial substance. More importantly, the mental can exist outside of the body, while the body itself is incapable of thought.

As a philosophical position, “substance dualism” seems compatible with Christian theology's claim that the immortal soul occupies an independent "realm" or space of existence distinct from that of the physical world. So - perhaps only the fully human part of Jesus was crucified. The fully divine section, on the other hand, merely took leave of the body, milled about in space or even intermissioned in hell, Hades or Sheol, buying time before Joseph of Arimathea appeared to first bury the fully human Jesus (the corpse) before the fully divine Jesus (the ever-living soul?) could re-enter the lifeless stiff. Only by positing substance dualism, it would seem, could one partially save Jesus' reputation from the problem either of resurrecting as a new being altogether and hence being an impostor, or from dying for two days or three days, and hence forfeiting his place in the Godhead. The problem, however, remains and seems to return by a viciously circuitous route. Can a soul re-entering a decomposed or decomposing body claim to be entering the same substance it exited? A rotting body is no different to a rotting log. It is not a legitimate living substance. It cannot be part of a duality. At least, this seems to be Boyle’s (1979: 198) view:

When a man is once really dead, divers of the parts of his body will, according to the course of nature, resolve themselves into multitudes of steams that wander to and fro in the air; and the remaining parts, that are either liquid or soft, undergo so great a corruption and change, that it is not possible so many scattered parts should be again brought together, and reunited after the same manner, wherein the existed in a human body whilst it was yet alive. And much more impossible it is to effect this reunion, if the body have been, as it often happens, devoured by wild beasts or fishes; since in this case, though the scattered parts of the cadaver might be recovered as particles of matter, yet 
already having passed into the substance of other animals, they are quite transmuted, as being informed by the new form of the beast or fish that devoured them and of which they now make a substantial part.

John Locke's ideas about same life and the atomic sameness of living things in An Essay Concerning Human Understanding seem also to question the possibility of the resurrection of the soul in a different body, thus essentially dismissing the importance soul/body duality (cf. Jolley 2015; Strawson 2011; Stewart 2000; Uzgalis 1990, 1988, 2007; Yolton 1956, 1969, 1970, 1984a, 1984b, 1990; Locke \& Yolton 1977; LoLordo 2010, 2012; Mattern 1980; Forstrom 2010). Nimbalkar 2011). Can dualism still be ascribed to a situation where only one of the previous parts of the duality exists, while the other part had expired? It could be ascribed, perhaps, were Jesus some kind of tobacco mosaic virus which is "dead" if "its constituent parts can be broken up and shaken into solution" only to "then selfassemble again into a viable virus capable of self-replication?" (Crippen \& Whetstine 2005; 202)

The seventeenth and eighteenth century opinion of the likes of Boyle, Browne (1643), Ross (1645), Pearson (1676), Tillotson (1682), Hody (1694), Wilson (1694), Holdsworth (1727), Felton (1733), and Fleury (1752) seems to be that, surely, some or all particles of the same pre-mortem body must persist, and the soul must somehow return to at least some part of that same old body. Indeed, the idea of a bodily resurrection is persistent from the early Church fathers such as Tertullian ${ }^{42}$, Athenagoras, ${ }^{43}$ Justin Martyr, ${ }^{44}$ Methodius ${ }^{45}$ and Rufinus ${ }^{46}$ to early modern times (Bynum 1990; Patrides 1958). If God's body and soul have separated for some days, can we still define the separated state as a duality? For instance, does not substance dualism always require the same, living body? Would it still be resurrection if God's soul mistakenly re-entered the body of one of the robbers who were crucified with Him? Does not duality equal two substances at all times? Does not the removal of one substance end the duality?

\footnotetext{
${ }^{42}$ Tertullian (1870). 'A treatise on the resurrection of the flesh', in: Alexander Roberts and James Donaldson

(eds.) Ante-Nicene Christian Library vol. XV: The Writings of Tertullian vol. II, Edinburgh: T. and T. Clark, 215-332.

${ }^{43}$ Athenagoras (1977). 'The treatise of Athenagoras on the resurrection of the dead', in: Alexander Roberts and

James Donaldson (eds.) The Ante-Nicene Fathers, Grand Rapids, MI: W.M. Eerdmans, II, 149-162.

${ }^{44}$ Martyr, J. (1909). 'Extant fragments of his lost work on the resurrection', in: Alexander Roberts and James Donaldson (eds.) Ante-Nicene Christian Library, Edinburgh: T. and T. Clark, II, 340-354.

${ }^{45}$ Methodius (1978). 'From the discourse on the resurrection', in: Alexander Roberts and James Donaldson (eds.) The Ante-Nicene Fathers, Grand Rapids, MI: W.M. Eerdmans, VI, 364-377.

${ }^{46}$ Rufinus (1955). A Commentary on the Apostles' Creed, trans. J. N. D. Kelly, London: Longmans, Green and Co., 78-86.
} 
Even if it is admitted that only the fully human Jesus died, while the fully divine floated and milled about and waited for re-entry at a suitable time, would this not confirm Nietzsche's suspicion that God can die and was dead? But, looked at closely, Nietzsche blaspheming does not lie where people think it lies, for the declaration of the death of God is nothing novel. Christians themselves hold that their God died for some two or so days. It is pleasantly surprising, anyway, that Nietzsche ultimately contradicts himself, for God cannot be declared to be dead. Only "God", in quotation marks, can die. That is, it is impossible to declare God's death. It is a waste of breath. If God wants to a soul to reenter a dog, a book or a stick in the mud, He can cause it to happen. He is God, after all.

The real blasphemy, in fact, is the assumption that God can do something as stupid as die. This is not a meaning that neither Nietzsche, Boyle nor Locke appear to fully appreciate. That neglected meaning is the one at the heart of this essay. God will not put his signature to stupid things. This is the only sense in which God will stop being God: by acting stupidly. A stupid God is not God. The stupidity principle will, ultimately, be discussed in detail in the section below.

All the sections of this article up to this point have had a single broad purpose: to discuss and evaluate the nature of Jesus, and to set the stage for enunciating the stupidity principle. The conclusion seems to be that Jesus is indeed God. They cannot be told apart, it is pointless to try to separate them. If we all agree that this is the case (that Jesus is God) we can the move to the next and most important part of the essay: the Jesus paradox. The Jesus paradox, as I hope to show, violates the stupidity principle. My hope is that the discussion up to this point has allowed me sufficient leeway to show that Jesus is God, that I should call Him God, and that every principle that applies to God applies to him.

\section{Towards the Jesus Paradox}

God is infinite in power. We know this: He has power over all creation. He is sovereign, and is able to do anything - precisely because He is God. There is nothing He cannot do (Matthew 19:26, Mark 10:27). One need only ask Job, who heard that God can feed lions, detain unicorns, and collar leviathans. ${ }^{47}$ Mulberry trees can be told to uproot themselves and plant themselves in the sea, without any hassles. If Palmer (1999: 25) is right, God “decides and causes all things to happen that do happen”. In Jeremiah 32:27, God says "Behold, I am the LORD, the God of all flesh: is there anything too hard for me?" ${ }^{48}$ Clearly, there is nothing too hard or too soft for God to do. There is no distance too far, or too near. He is Omnipresent, and goes where He wants and has eyes

\footnotetext{
47 “Then Job answered the LORD, and said, I know that thou canst do everything” (Job 42:1-2)

${ }^{48}$ Jeremiah is simply giving credit where it is due when he rightly observes "Ah Lord God! ... there is nothing too hard for thee" (Jeremiah 32: 17)
} 
everywhere. ${ }^{49}$ God is not afraid of anyone, or of anything. He is the Father of Creation, and He is Omnipotent. After all, He made everything that exists to be. The only thing that He did not make is Himself, and that only because He was always around and has no beginning or end. He is, in all senses of the word, God.

It follows that were there to be something that God has never done, it is probably because He merely chooses not to do it. But we know He could do it if He wanted. Just because God lets evil happen does not mean that He cannot stop it, or is afraid of it. Just because He does not respond to your prayer the way you want does not mean He has not heard you or is unable to respond. It is just that His way are mysterious. This is the meaning of being God, and of being Omnipotent. We hear that "God ... does not lie." (Titus 1:2), and that it is "impossible for God to lie" (Hebrews 6:18). ${ }^{50}$ This does not mean that He cannot do it if He wanted, since nothing fazes him. What can stop him?

Just because God does not do it, or says He is not going to do it, does not mean that He cannot do it. As Thomas Aquinas argues, God is not impotent: "Better, however, to say that it cannot be done, rather than God cannot do it." ${ }^{51}$ For instance, the fact that God has not destroyed evil yet (as promised in Revelations) might be ultimately frustrating, but it does not mean that He cannot do what He promised. We must assume that he knows what He is doing. In the words of Augustine of Hippo, "He cannot do some things for the very reason that He is omnipotent". ${ }^{52}$ Just because he does not do it does not mean that He does not possess the infinite power to do it. He just chooses not to, in his infinite wisdom. That is, He does not do stupid things. This the only reason that God cannot make a rock so big that even He cannot lift it. That is, He will not act contrary to His own character and nature, because to do so would just be stupid, and God cannot be seen to be stupid, not because He cannot do it. This is the stupidity principle on whose violation Christianity seems to be based. The principle partly arises from Galatians 6: 7 ("Be not deceived; God is not mocked: for whatsoever a man soweth, that shall he also reap”) and from Psalm 14: 1 (“To the chief Musician, A Psalm of David. The fool hath said in his heart, There is no God. They are corrupt, they have done abominable works, there is none that doeth good").

The stupidity principle resolves all other "paradoxes", for instance. The so-called omnipotence paradox, expressed famously in the statement of a rock so heavy that its

\footnotetext{
${ }^{49}$ His eyes "run to and fro throughout the whole earth" (2 Chronicles 16:9).

50 "That by two immutable things in which it was impossible for God to lie, we might have a strong consolation, who have fled for refuge to lay hold upon the hope set before us.” (Hebrews 6:18)

51 Aquinas, T. Summa Theologica p. 163-164, Volume I, ques. 15 ans. 3.

52 "For He is called omnipotent on account of His doing what He wills, not on account of His suffering what He wills not; for if that should befall Him, He would by no means be omnipotent. Wherefore, He cannot do some things for the very reason that He is omnipotent." City of God, Book V, 10, "Whether our wills are ruled by necessity" Trans. J.J. Smith.
} 
omnipotent creator cannot lift it, will be shown not to be a paradox at all. As an attempt to mock God, it will not work because God does not reap what He sows. More importantly, such a "stone" paradox is an attempt to place God into a contradiction He cannot get out of. But such a move will not work because God cannot and will not enter into such a contradiction in the first place. That is, He is not a fool. God cannot be both God and the fool who says in his heart there is no God. God cannot not be God! The paradox resolves itself, because the fool has to be someone else. The joke has to be on another person, who is not God. God cannot be both Himself and the fool who denies God.

Hence God who creates a stone so large he cannot lift it is a foolish God. That is, He is not God and cannot be God. Essentially, God is insulated from such stupidity. God who does that is a stupid God, and a stupid God has no business being God, and does not deserve to be God. The question that leads to the lifting-a-rock paradox (Can God lift a stone larger than he can carry?) is a stupid question, and does not deserve an answer. ${ }^{53}$ An omnipotent being, unless he is a stupid omnipotent being, is not going to create a stone so large he cannot lift it. That should be enough to resolve the so-called paradox.

We began this essay with the question: Can a thing be what it is not, and not be what it is? Can a thing be where it is not, and not be where it is? Can God not be God? The answer is provided in the dununu principle. God cannot be who He is not, or not be who He is. God cannot be where He is not, or not be where He is. An omnipotent being is not going to create a triangle whose internal angles do not add up to 180 degrees, ${ }^{54}$ because - were such a triangle to be communicable - that would be a stupid thing to do. Does Aquinas think God is stupid? Descartes in Principia philosophiae claims that God is precluded from creating things so indivisible that He could not divide them. Again, Descartes thinks that God is stupid.

Geach (1973) attempts to restrict God's omnipotence because - he reasons - an all-powerful God is able to do all that is logically possible, such as breaking His word. But this is nonsense. Such a solution is flawed, because it pleads with God to afford not to be God. It pleads with God to play the fool. None of Mavrodes' (1963) solutions concerning omnipotence, Geach's (1973) four restrictions, Wade's (1967) attempted solutions to the paradox of the Stone, Aquinas triangle, or Descartes' indivisible things, and so on, say anything about God's logical insulation from stupidity. The only true solution is to highlight the dununu principle: that account of the things that God, being God, would rather not do and would rather not be seen doing.

\footnotetext{
${ }^{53}$ CS Lewis (1996) suggests that such a question is nonsense, but appears to contradict himself when he goes on to try to show that it is nonsense.

${ }^{54}$ Aquinas, T. Summa Contra Gentiles, Book 2, Section 25.
} 
The stupidity principle seems a core principle in the whole business of being God. For instance, can "kill and... make alive... wound and...heal", if He wanted to, and "there is none that can" do anything about it (Deuteronomy 32:39-40). Contrary to what Mavrodes says, these are not "pseudo-tasks". Nothing that God has created is false, just as nothing that He has created can have power over the Creator. He can kill and make a life and wound and heal in equal measure. That is, God can lie, cheat, hurt and steal, if He wanted to. But because He is God, He cannot and wold rather not do such things. It would just seem stupid for Him to, and God is not stupid. In CS Lewis (1996: 25) view:

It remains true that all things are possible with God: the intrinsic impossibilities are not things but nonentities. It is no more possible for God than for the weakest of His creatures to carry out both of two mutually exclusive alternatives; not because His power meets an obstacle, but because nonsense remains nonsense even when we talk it about God.

I will not go as far as CS Lewis (1996: 25) to say that people who craft paradoxes of omnipotence "have not succeeded in saying anything about God". I do think that they have said something about God, but have not gone far enough. Were they to go as far as should be possible, they would see that God is constrained by stupidity. God cannot be a blockhead. He cannot be a dununu and still remain God. That is, He can create a rock so large He cannot lift it if He wanted, but He is never going to do that. What would that achieve? He will just be a laughing stock. In other words, it is not really that one cannot attribute nonsense to God. One can, actually. Why not? It is simply that, attribution aside, God is not going to go ahead and make a fool of Himself.

Hence God has power over everything that is seen and is not seen, the communicable and the incommunicable. Being God means that He does what He wants, whenever He wants, wherever He wants, to whomever He wants, however he wants. Who is to say otherwise? The only reason God does not do things that are out of character is not because He cannot do things that are out character. He can. He is God, after all. There is nothing that God cannot do. That is, He would not be God if it could be proved that there is something that He could not do, that He is afraid of doing, or that He is precluded from doing. Hence:

Whatever implies being and nonbeing simultaneously is incompatible with the absolute possibility which falls under divine omnipotence. Such a contradiction is not subject to it, not from any impotence in God, but because it simply does not have the nature of being feasible or possible. Whatever, then, does not involve a contradiction is in the realm of the possible with respect to which God 
is omnipotent. Whatever involves a contradiction is not within the scope of omnipotence because it cannot qualify for possibility. ${ }^{55}$

If I am to summarise Aquinas here, all he seems to be saying is that God cannot be (seen to be) stupid. The only reason God does not lie, cheat, steal, break promises and abandon his children is because He is God. That is, He is not stupid. This assertion brings us to the main thesis of this essay: that the main thing that God cannot do is violate the stupidity principle.

The distinction that seems to mark the ultimate separation between God and human beings indeed seems to be this: God can do anything, human beings cannot. Hence, "With man this is impossible, but with God all things are possible" (Matthew 19:26). There are many things, for instance, that physical laws suggest human beings cannot do, whether they like it or not. For instance, it is not known whether human beings can live forever. But God can. The Jesus paradox can only make sense if we establish, without any shade of doubt, the God-ness of God, the fact that nothing is impossible with God and that there is nothing too difficult for Him (Genesis 18:9-15). This God-ness is what Sarah found out, a bit too late, after she had already laughed. She laughed because, for a moment, she allowed herself to forget who God was. Worse, she dared deny to God that she had laughed!

Ninety-year old Sarah was able to give birth (as did another aged woman, John the Baptist's mother, Elizabeth), in answer to the question: "Is anything too hard for the LORD?" (Genesis 18:14). God was displeased that Moses allowed himself to doubt God's power in the saga of the water from the rock. Moses should have known better, for God had made food appear in the desert to feed 600,000 soldiers and their families, His hand never waxing short. God made the sun stop in its tracks for Joshua, and made Gideon's army of 300 teach a lesson to an army of 32,000. To Mary's silly question, "How will that work, since I am a virgin?" the angel Gabriel retorts, "Nothing's impossible with God." (Luke 1:37). All this is not boasting. It is just who God is.

The "Jesus paradox" arises directly because of the insupportable claim the Jesus died on the Cross. The principle of stupidity, which "prohibits" God from making a rock so big that He cannot lift it, does not apply in the case of death for the simple reason that God appears to allow the possibility of dying (John 3: 16). ${ }^{56}$ If it was a stupid experiment, God would not have gone ahead with it. Since God does not seem to do stupid things, we must assume that the plan to have Jesus die is not stupid. The problem is that following through with the promise to give away Jesus to death is accept the possibility that God could die.

\footnotetext{
${ }^{55}$ Aquinas, T. Summa Theologica p. 163-164, Volume I, ques. 15 ans. 3.

56 "For God loved the world so much that he gave his one and only Son, so that everyone who believes in him will not perish but have eternal life."
} 
We have said that God does not do stupid things, so what is behind this seemingly terrible decision to experiment with Death? Is the "death" of Jesus stupid?

The death of Jesus seems to either be strategic or stupid (or strategically stupid, or stupidly strategic), because of a unique discovery: that there is, in fact, one true thing that God cannot do: dying. God cannot die. It would be stupid of Him to do so. That is, He cannot stop being God. Any assertion that God dies is blasphemous, for it points out that God can act out of character, and that, ultimately, He actually does stupid things.

Let us first grant that God cannot die, that He is not stupid. What is the outcome of this? It leads to a paradox. God who is not stupid looks stupid. It is a vicious circle. How? Granting that God cannot die seems to contradict His being God. That is, dying is the one incontrovertible thing that we know God cannot ever do and that, in fact, He dares never to do. The point is: as long as God cannot do this one thing, He cannot lay claim to being God. That is, while it is not stupid for God not to want to die, it seems rather stupid of Him to be unable (and perhaps afraid) to die.

As we granted earlier, God ought to be able to do anything and everything that is doable. God ought to have power to do all those things He chooses to do (for instance, live forever, or resurrect the dead), as well as all those things that He merely chooses not to do (for instance, die for a few days, stop being God, go to sleep, or cause evil ${ }^{57}$ ). If God cannot physically die, then Death would seem to supersede God? Logically, anything which God cannot manage to do, it would seem, becomes greater and more powerful than God, and therefore becomes God. But it seems stupid for God to allow, even to provide for, the existence of anything that is greater than Him. We are thus caught in the vicious grip of the stupidity principle.

Essentially, the paradox which traps Jesus is that He needs to die in order to show that He is God, but by dying He forfeits being God. Christianity, we know, hinges on the doctrine of the Resurrection. That is, Christianity hangs on stupidity: the assumption that its Deity dies. The assumption that God dies is no different to the categorical mistake that questions whether God can make a rock so large that He cannot lift it. Can God die knowing He cannot die? Can God afford to die knowing He cannot afford to die? Either way we turn, we cannot have Christianity without violating the stupidity principle. The affirmation of God's stupidity means that Christianity is a hoax, because God cannot (afford to) be stupid. Indeed, mainstream Christianity is, in this regard, completely heretical.

Another small but not insignificant stupidity problem raised by the Jesus paradox, of course, is its classic use of abusus non tollit usum principle. Christianity is constructed

57 "Let no one say when he is tempted, "I am being tempted by God," for God cannot be tempted with evil, and he himself tempts no one”. (James 1: 13) 
on God's murder, or the error of His murder, on the cross and His resurrection three days later. That is, God was falsely accused (injustice, error, evil, crime), tortured (injustice, error, evil, crime) and summarily executed (injustice, error, evil, crime) by the Romans, partly at the sinister instigation of the Pharisees. From the false witness, trumped up charges, torture, and murder out comes Christianity (justice, right, good, redemption). The errors, the evil and the injustice of the betrayers, false accusers, torturers and murderers of Christ seem to be merely instruments in what then becomes the inevitable, staged triumph of God over death and ultimately over the sins of the world. Out of murder, error, torture, injustice and wrong came a redemptive religion.

But can good ever come out of evil? If this were the case, it would again suggest that God has broken with the stupidity principle. The principle of abusus non tollit usum is always and completely illogical, contradictory and unethical. Good can never come out of evil. That good may temporally succeed evil does not mean that good is coming out of evil. Good is despite, and in spite of, evil. It seems illogical, for instance, to see Christianity as the outcome of Jesus' murder, execution and death on the cross. Ethical religion cannot, it seems, benefit from murder, whether of its God, chief prophet or anyone else. Christianity has to be the outcome despite and in spite of Jesus' murder on the cross. Perhaps we can say good triumphs over evil, but it cannot issue forth out of evil. Good cannot metamorphose out of evil, and God cannot metamorphose out of the devil. That can never make sense.

What I have sought to establish is that the resurrection story does not make sense because it fails to take note of a simple fact: only God's humanity could die on the cross. But why? Because God is unable to simulate death. Humanity is the only thing that can die. Only humanity is mortal and subject to death. Hence death is the one thing, the one place, where Humanity can go but God is not stupid enough not go. Deities do not die. This is an impossibility. Because God cannot die, He is hence imprisoned in immortality. The one thing God is not stupid enough to try is to dare experiment with losing His own death. If the resurrection story is true, then God sacrifices His fully Human self on the Cross, not his Divine self. For He cannot do both. This is a contradiction He would rather not resolve. Only stupid people attempt to resolve such a contradiction. Jesus as Son of Man was crucified on Calvary, buried, and raised up again on the third day. Who raised him up? The Son of God - the one who could not die. God cannot die. This must not be interpreted to mean that God chooses not to die. It is not a choice. Rather, He cannot, and will not, do it - because He is God. God, by nature, cannot choose.

It would seem that, in light of the above considerations, that a sovereign God has no business dying. Where we hear that God has died, we must flag this as a potential scam. The reason is that we have established that God has no truck with stupidity, and the death of God seems stupid. 


\section{By Way of Conclusion}

This article has unveiled the "Jesus Paradox" and attempted to solve it using the Bible' s own tools. I began by posing the question: is Christianity a hoax? The answer seemed to hinge on another, much more basic question: Did/can God die? These questions were threaded into a larger theoretical and philosophical question: Can a thing be what it is not, and not be what it is? Can a thing be where it is not, and not be where it is? I established that God can do whatever He wants - He is God after all. He can be man, God, God-man, man-God, or all these at once. God can do whatever He wants, but to not be God is not to do what He wants. Hence, the only thing God cannot do is die. I established that, because God cannot die, resurrection and Christianity are irrelevant.

Mainstream church doctrine's solution is to fudge the question, and hide behind the averment that the answer is beyond human understanding. That is, one must simply have faith, supposedly because what the Ecumenical Councils decreed must be true. But this is demagoguery and nonsense. The appeal to faith has little use in matters of God. I conclude that church doctrine handed down from the Ecumenical Councils masks the fact that Christianity is built on and sustained by heresy. Easter is a heretical holiday and commemoration. By heretical, I mean to be a dununu, or just plain stupid. Anyone who admits the possibility of the death of God is quite simply stupid. The solution by philosophers, scholars and theologians is no better than that of the church fathers. They pose useless "paradoxes", such as the paradox of the stone. There is no way God can be justified through reference to a stone, a triangle, or whatever. All of this is stupid. The solution is to insulate oneself from stupidity.

A provisional conclusion is that Christianity needs to sort out its origins. It is clear that a major heresy lies at the heart of the story of Christianity: the stupid Easter idea or belief that God passed away. The two solutions that exist both expose this contradiction. The first solution is to believe that God really died on that tempestuous Good Friday in $1^{\text {st }}$ century Judea, and was resurrected on the Sunday. Such a solution would compel Christology to recognise the possibility that God who went to heaven forty days after resurrection is an impostor, since God who dies deserves to stay dead. God who dies, even for five seconds, is not God, is a cretin, a blockhead and an impostor.

The second solution is to consider Jesus as not having died, since God cannot die. This, however, raises the possibility of a staged death and resurrection. Either way, the provisional conclusion finds that Christianity seems founded on a hitherto neglected but important, untenable heresy. That is, Christianity as a religion does not exist, is impossible, and is a hoax because it is premised on the stupidity of God. Perhaps I could be accused of having created and destroyed a straw man, but it can be easily demonstrated that this is far from the case. The article rests on consistent and 
supportable claims. Is it creating a straw man to ask "Could God die"? Is it destroying a straw man to conclude that God is immortal? Is it destroying a straw man to conclude that God cannot die?

In the end, it was possible to reach an even more substantive deduction. A thing can neither be what it is not, nor not be what it is. A thing can neither be where it is not, nor not be where it is. God is God, indivisibly so. This conclusion leads to my closing statements: that mainstream Christianity, as inherited from the Ecumenical Councils, is at heart heretical and is incompatible with the word of God. The only way for Christianity to be compatible with the word of God is for it to stop the propagating and believing the pagan nonsense that God died on the Cross, or anywhere else. God does not die. The only ethical solution is for Christianity is to abolish itself, start afresh, and find God again on the basis of a new principle not grounded in boneheaded stupidity or utununu. 


\section{REFERENCES}

Agar, N. (2004). Liberal Eugenics: In Defence of Human Enhancement. Malden, MA: Blackwell. Agar, N. (2010). Humanity's End: Why We Should Reject Radical Enhancement. Cambridge, MA: MIT Press.

Agar, N. (2013). Truly Human Enhancement: A Philosophical Defense of Limits, Cambridge MA: MIT Press.

Alexander, B. (2003). Rapture: How Biotech Became the New Religion. New York: Basic Books.

Allenby, B.R. \& D. Sarewitz (2011). The Techno-Human Condition. Cambridge, MA: MIT Press.

Allison, D.C. (1985). The End of the Ages Has Come: An Early Interpretation of the Passion and Resurrection of Jesus. Philadelphia: Fortress.

Allison, D.C. (2005). Resurrecting Jesus: The Earliest Christian Tradition and Its Interpreters. New York: T\&T Clark.

Ames, C.C (2015). Medieval Heresies: Christianity, Judaism, and Islam, Cambridge: Cambridge University Press.

Anderson, K.L. (2006). "But God Raised Him from the Dead”: The Theology of Jesus" Resurrection in Luke-Acts. PBM. Milton Keynes, UK: Paternoster.

Anderson, W.P. (2010). A Journey through Christian Theology, 2nd Edition. Minneapolis, MN: Fortress Press.

Andrews, L.B. (2001). Future Perfect: Confronting Decisions about Genetics. New York: Columbia University Press.

Ansell-Pearson, K (1997). The Transhuman Condition: A Report on Machines, Technics, and Evolution. London: Routledge.

Aquinas, T. (1955). Summa Contra Gentiles, Book II, Trans. J.F. Anderson, New York: Hanover House, http://dhspriory.org/thomas/ContraGentiles.htm. Retrieved 15 May 2017.

Aquinas, T. Summa Theologica, http://www.saintwiki.com/index.php?title=The_Summa_Theologica. Retrieved 15 May 2017.

Asad, T. (1986). Medieval Heresy: An Anthropological View, Social History 11(3), 345362. 
Augustine of Hippo, The City of God against the Pagans, http://www.saintwiki.com/index.php?title=Augustine/The_City_of_God. Retrieved 15 May 2017.

Aus, R.D. (2008). The Death, Burial, and Resurrection of Jesus and the Death, Burial, and Translation of Moses in Judaic Tradition. Lanham, MD: University Press of America, 2008.

Avis, P., (1993). (ed.), The Resurrection of Jesus Christ. London: Darton, Longman \&Todd.

Ayers, L. (2006). Nicaea and Its Legacy, New York: Oxford University Press.

Badmington, N. (2000). (ed.), Posthumanism. Palgrave.

Baggett, D.J. (2009). (ed.), Did the Resurrection Happen? A Conversation with Gary Habermas and Antony Flew. Downers Grove, IL: InterVarsity Press.

Baillie, H.W. \& T.K. Casey. (2004). (eds.), Is Human Nature Obsolete? Genetics, Bioengineering, and the Future of the Human Condition. Cambridge, MA: MIT Press.

Baker, D. (1972). (ed.), Schism, Heresy and Religious Protest, Cambridge: Cambridge University Press.

Bamford, S. (2012). A Framework for Approaches to Transfer of a Mind's Substrate. International Journal of Machine Consciousness 4 (01),23-34.

Barker, M. (1996). The Risen Lord: The Jesus of History and the Christ of Faith. Valley Forge, PA: Trinity Press International.

Barnes, M.R. \& Williams, D.H. (1993). (eds.), Arianism after Arius: Essays on the Development of the Fourth Century Trinitarian Conflicts, Edinburgh: T. \& T. Clark.

Barrat, J. (2013). Our Final Invention: Artificial Intelligence and the end of the Human Era. Thomas Dunne Books.

Bartlett, E. \& S. Youngner (1988) "Human Death and the Destruction of the Neocortex," in R. Zaner (ed.), Death: Beyond Whole-Brain Criteria, Dordrecht, Netherlands: Kluwer.

Bateman, S., J. Gayon, S. Allouche, J. Goffette, \& M. Marzano (2015). (eds.), Inquiring into Human Enhancement: Interdisciplinary and International Perspectives. New York: Palgrave Macmillan. 
Beard, J. (2000). How We Became Posthuman: Virtual Bodies in Cybernetics, Literature, and Informatics. Knowledge, Technology \& Policy 13 (1), 114-115.

Beasley-Murray, G. R. (1964). The Resurrection of Jesus Christ. London: Oliphants.

Beasley-Murray, Paul. (2000). The Message of the Resurrection. Downers Grove, IL: InterVarsity Press.

Becker, L. (1975). Human Being: The Boundaries of the Concept, Philosophy and Public Affairs, 4: 334-59.

Bellitto, C.M. (2002). The General Councils: A History of the Twenty-One Church Councils from Nicaea to Vatican II. Mahwah, NJ: Paulist Press.

Benedikter, R. \& Siepmann (2016). The Philosophical Basis of "Transhumanist" Politics: Analyzing the Future of Transhumanist Ideology Based on the Book The Transhumanist Wager. Essays in the Philosophy of Humanism 24 (1), 103-114.

Benford, G. \& E. Malartre (2007). Beyond Human: Living with Robots and Cyborgs. New York: Tom Doherty Associates.

Berkhof, L. (1996). Systematic Theology. Grand Rapids: Eerdemans.

Berkhout, C.T. \& Russell, J.B. (1981). Medieval Heresies: A Bibliography 1960-1979, Toronto: Pontifical Institute of Mediaeval Studies.

Berlinerblau, J. (2001). Toward a Sociology of Heresy, Orthodoxy and Doxa, History of Religions 40 (4), 327-351.

Bernat J.L., Culver C.M., Gert B. (1981). On the definition and criteria of death. Annals of Internal Medicine. 11, 389-394.

Bernat, J.L (2006). Are Organ Donors after Cardiac Death Really Dead?” Journal of Clinical Ethics 17, 122-32.

Bernat, J.L. (1992). How Much of the Brain Must Die on Brain Death, Journal of Clinical Ethics, 3 (1), 21-26.

Bernat, J.L. (1998). A Defense of the Whole-Brain Concept of Death, Hastings Center Report, 28 (2), 14-23.

Bernat, J.L. (2006). The Whole-Brain Concept of Death Remains Optimum Public Policy, Journal of Law, Medicine \& Ethics, 34 (1), 35-43. 
Bernat, J.L. (2010). How the Distinction between 'Irreversible' and 'Permanent' Illuminates

Circulatory-Respiratory Death Determination, Journal of Medicine and Philosophy, 35, 242-255.

Bernat, J.L. (2014). Whither brain death? The American Journal of Bioethics, 14(8):3-8.

Best, B.P (2008). Scientific justification of cryonics practice. Rejuvenation Research. 11 (2): 493503.

Binz, S.J. (1989). The Passion and Resurrection Narratives of Jesus: A Commentary.

Collegeville, MN: Liturgical Press.

Bishop, J.P. (2010). Transhumanism, Metaphysics, and the Posthuman God. Journal of Medicine and Philosophy 35 (6), 700-720.

Blackford, R. \& D. Broderick (2014). (eds.), Intelligence Unbound: The Future of Uploaded and Machine Minds.Wiley-Blackwell.

Blackford, R. (2013). Humanity Enhanced: Genetic Choice and the Challenge for

Blackman, E.C. (1978). Marcion and His Influence, New York: Ames Press.

Blomberg, C.L. (1987). The Historical Reliability of the Gospels. Downers Grove, IL:

InterVarsity.

Bokenkotter, T. (2004). A Concise History of the Catholic Church, New York:

DoubleDay.

Bostrom, N. (2003a). Are You Living In A Computer Simulation? Philosophical Quarterly 53, (211) 243-255.

Bostrom, N. (2003b). Human Genetic Enhancements: A Transhumanist Perspective, Journal of Value Inquiry 37 (4), 493-506.

Bostrom, N. (2005a). In Defense of Posthuman Dignity. Bioethics 19 (3), 202-214.

Bostrom, N. (2005b). A History of Transhumanist Thought, Journal of Evolution and Technology $14(1), 1-25$.

Bostrom, N. (2005c). Transhumanist Values. Journal of Philosophical Research 30, 3-14.

Bostrom, N. (2006). A Short History of Transhumanist Thought. Analysis and Metaphysics 5, 6395. 
Bostrom, N. (2014). Superintelligence: Paths, Dangers, Strategies. Oxford UK: Oxford University Press.

Bova, B. (2000). Immortality: How Science is Extending Your Life Span - and Changing the World. New York: Harper Perennial.

Boyle, R. (1979). "Some Physico-Theological Considerations about the Possibility of the Resurrection”, in: Selected Philosophical Papers of Robert Boyle, ed. M.A. Stewart, Manchester University Press, New York.

Bray J.G. (1993). The Lazarus phenomenon revisited. Anesthesiology 78, 991.

Bright, W. (1892). The Canons of the First Four General Councils of Nicaea, Constantinople, Ephesus and Chalcedon: With Notes, Oxford: Clarendon Press.

Brody, B. (1999). How Much of the Brain Must be Dead? In: S. Youngner, R. Arnold, and R. Brooke, C.N. L. (1968). Heresy and Religious Sentiment: 1000-1250, Bulletin of the Institute of Historical Research 41, 115-131.

Brown, R.E. (1973). The Virginal Conception and Bodily Resurrection of Jesus. New York: Paulist Press, 1973.

Browne, T. (1643) Religio medici, in: Browne, Major Works. C.A. Patrides (1977). (ed.) Harmondsworth, 59-161.

Bruce, F.F. (1960). The New Testament Documents: Are they reliable? Downers Grove, IL: InterVarsity

Buchanan, A. (2011a). Better than Human: The Promise and Perils of Enhancing Ourselves. New York: Oxford University Press.

Buchanan, A. (2011b). Beyond Humanity? The Ethics of Biomedical Enhancement. Oxford University Press.

Burn, A.E. (1925). The Council of Nicaea: A memorial for its sixteenth centenary, London: SPCK.

Bynum, C.W. (1990). Material continuity, personal survival, and the resurrection of the body: a Scholastic discussion in its medieval and modern contexts, History of Religions, $30,51-85$. 
Bynum, C.W. (1995). The Resurrection of the Body in Western Christianity, 200-1336.

New York: Columbia University Press.

Cabrera, L.Y. (2015). Rethinking Human Enhancement: Social Enhancement and Emergent Technologies. New York: Palgrave Macmillan.

Capron, A.M. (1999). The Bifurcated Legal Standard for Determining Death, in: S. Youngner, R. Arnold \& R. Shapiro (eds.), The Definition of Death: Contemporary Controversies, Baltimore, MD: Johns Hopkins University Press, 117-136.

Carroll, W. (1987). The Building of Christendom, Front Royal: Christendom College Press.

Caterina B. \& P. Biller (2003). (eds.), Texts and the Repression of Medieval Heresy, York: York Medieval Press.

Cecchetto, D. (2013). Humanesis: Sound and Technological Posthumanism. Minneapolis, MN: University of Minnesota Press.

Chesnut, R.C. (1976). Three Monophysite Christologies, Oxford: Oxford University Press. Chidester, D. (2000). Christianity: A Global History. New York: HaperCollins Publishers. Chorost, Michael. (2011). World Wide Mind: The Coming Integration of Humanity, Machines, and the Internet, Freepress.

Christie-Murray D. (1976). A History of Heresy, Oxford: Oxford University Press.

Churton, T. (1987). The Gnostics, London: Weidenfeld and Nicolson.

Clarke, M.J., Remtema, M.S. \& Swetz, K.M. (2014). Beyond transplantation: considering brain death as a hard clinical endpoint. The American Journal of Bioethics 14(8):43-5.

Clifton, C.S. (1992). Encyclopedia of Heresies and Heretics. New York: Barnes and Noble Books.

Cohen, C. (2012). Bioethicists must rethink the concept of death: the idea of brain death is not appropriate for cryopreservation, Clinics 67(2), 93-94.

Cohn, N. (2000). Europe's Inner Demons: The Demonization of Christians in Medieval Christendom, Chicago: The University of Chicago Press.

Cole-Turner, R. (2001). (ed.), Beyond Cloning: Religion and the Remaking of Humanity. Harrisburg, PA: Trinity Press International. 
Cole-Turner, R. (2011). (ed.), Transhumanism and transcendence: Christian hope in an age of technological enhancement. Washington, D.C.: Georgetown University Press.

Collins, M. (2010). Reevaluating the dead donor rule. Journal of Medicine and Philosophy. 35(2):154-79.

Copan, P. (1998). (ed.), Will the Real Jesus Please Stand Up? A Debate between William Lane Craig and John Dominic Crossan. Grand Rapids: Baker Academic.

Cowan, J. L. (1978). "The Paradox of Omnipotence, in: Urban, L. \& D. Walton (eds.) The Power of God: Readings on Omnipotence and Evil, Oxford: Oxford University Press, 14452.

Craig W.L. \& C. Meister (2009). God is Great, God is Good, Downers Grove, IL: InterVarsity.

Craig, W.L. (1981). The Son Rises: Historical Evidence for the Resurrection of Jesus, Chicago: Moody Press.

Craig, W.L. (1988). (eds). Knowing the Truth about the Resurrection: Our Response to the Empty Tomb. Ann Arbor, MI: Servant Publications.

Craig, W.L. (1989). Assessing the New Testament Evidence for the Historicity of the Resurrection. Lewiston, NY: Mellen.

Craig, W.L. (1994). Reasonable Faith, Wheaton, IL: Crossway

Cranford, R. (1995). Criteria for Death, in: W. Reich (ed.), Encyclopedia of Bioethics, 2nd ed. New York: Macmillan, 529-534.

Crippen, D.W. \& L.M Whetstine (2007). Ethics review: Dark angels - the problem of death in intensive care, Critical Care, 11(1), 202.

Crossan, J.D. (1991). The Historical Jesus, San Francisco: HarperSanFrancisco.

Davis, L.D. (1983). The First Seven Ecumenical Councils (325-787), Collegeville: Liturgical Press.

Davis, S.T., Kendall, D. \& G. O’Collins (1997). (eds.), The Resurrection: An Interdisciplinary Symposium on the Resurrection of Jesus. New York: Oxford University Press. 
Deane, J.K. (2010). A History of Medieval Heresy and Inquisition, Lanham: Rowman \& Littlefield 2010.

Deech, R. \& A. Smajdor (2008). From IVF to Immortality: Controversy in the Era of Reproductive Technology. New York: Oxford University Press.

DeGrazia, D. (1999). Persons, Organisms, and Death: A Philosophical Critique of the HigherBrain Approach, Southern Journal of Philosophy, 37: 419-40.

DeGrazia, D. (2014). The Nature of Human Death, in: S. Luper (ed.), The Cambridge Companion to Life and Death, Cambridge: Cambridge University Press: 80-100.

deGrey, A. \& M. Rae. (2007). Ending Aging: The Rejuvenation that Could Reverse Human Aging in Our Lifetime. New York: St. Martin's Press.

Denzinger, H. (1957). The Sources of Catholic Dogma, Trans. R.J. Deferrari, St. Louis, Mo.: B. Herder Book Co.

Descartes, R. (1983 [1644]) Principia philosophiae/Principles of Philosophy. Trans. Rodger, V. \& R. P. Miller, Dordrecht: Reidel

Dewdney, C. (1998). Last Flesh: Life in the Transhuman Era. New York: HarperCollins.

Doyle, D.J. (2012). Cryonic Life Extension: Scientific Possibility or Stupid Pipe Dream? Ethics in Biology, Engineering and Medicine: an International Journal. 3 (1-3): 9-28.

Doyle, R. (2003). Wetwares: Experiments in PostVital Living. University of Minnesota Press.

Drexler, K.E. (1986). Engines of Creation: The Coming Era of Nanotechnology (New York: Anchor Books.

Durrwell, F-X. (2002). Christ Our Passover: The Indispensable Role of the Resurrection in Our Salvation. Trans. J.F. Craghan. Liguori, MO: Liguori.

Edwards, M.J. (2009). Catholicity and Heresy in the Early Church, Burlington, VT: Ashgate Publishing, Ltd.

Ehrman, B.D. (2003). Lost Christianities: The Battles for Scripture and the Faiths We Never Knew. New York: Oxford.

Eilers, M., K. Gruber \& C. Rehmann-Sutter (2014). (eds). The Human Enhancement Debate and Disability: New Bodies for a Better Life. New York: Palgrave Macmillan. 
Elliott, R.L \& Budwany R. (2014). When is brain dead not dead enough? The Journal of the Medical Association of Georgia 103(1), 12-3.

Engelhardt, H.T. (1975). Defining Death: A Philosophical Problem for Medicine and Law, Annual Review of Respiratory Disease, 112, 312-24.

Enhancement, New York: Broadway.

Ettinger, R. (1964). The Prospect of Immortality, New York: Doubleday.

Ettinger, R. (1972). Man into Superman, New York: St. Martin’s.

Fahy, G.M, Saur J. \& Williams R.J. (1990). Physical problems with the vitrification of large biological systems. Cryobiology 27 (5): 492-510.

Fahy, G.M., Wowk B., Wu J., Phan J., Rasch C., Chang A. \& Zendejas E. (2004).

Cryopreservation of organs by vitrification: perspectives and recent advances. Cryobiology 48(2), $157-78$

Fairbairn, D. (2003). Grace and Christology in the Early Church, Oxford: Oxford University Press.

Faivre, A. (2000). Theosophy, Imagination, Tradition: Studies in Western Esotericism. Albany: State University of New York Press.

Felton, H. (1733). The Resurrection of the Same Numerical Body, and its Reunion to the Same Soul; asserted in a Sermon preached before the University of Oxford, at St. Mary's. On Easter-Monday, 1725 (London: Motte)

Fereidoun M.E. (1989). Are You a Transhuman?: Monitoring and Stimulating Your Personal Rate of Growth in a Rapidly Changing World. New York: Warner Books.

Filoramo, G. (1990). A History of Gnosticism. Oxford: Blackwell.

Finegan, J. (1992). The Archaeology of the New Testament. Princeton: Princeton University Press.

Fleury, A. (1752). A Short Essay on the General Resurrection: Wherein It Is Proved, that We Shall Rise with the Same Bodies that we Now Have, Dublin: S. Powell.

Forell, G.W. (1965). Understanding the Nicene Creed, Philadelphia: Fortress Press.

Forstrom, K.J.S. (2010). John Locke and Personal Identity: Immortality and Bodily

Resurrection in 17th-Century Philosophy, Continuum. 
France, R.T. (1986). The Evidence for Jesus. Downers Grove, IL: InterVarsity

Frassetto, M. (2006). (ed.), Heresy and the Persecuting Society in the Middle Ages: Essays on the Work of R. I. Moore, Leiden: Brill.

Frassetto, M. (2007). Heretic Lives: Medieval Heresy from Bogomil and the Cathars to Wyclif and Hus, London: Profile Books.

Frend, W.H.C. (1952). The Donatist Church: A Movement of Protest in Roman North Africa, Oxford: Oxford University Press.

Frend, W.H.C. (1972). The Rise of the Monophysite Movement. Cambridge: University Press

Fröding, B. (2013). Virtue Ethics and Human Enhancement. New York: Springer.

Fukuyama, F. (2002). Our Posthuman Future: Consequences of the Biotechnology Revolution. New York: Picador.

Fuller, S. (2011). Humanity 2.0: What It Means to Be Human Past, Present, and Future. New York: Palgrave Macmillan.

Garreau, J. (2006). Radical Evolution: The Promise and Peril of Enhancing Our Minds, Our Bodies - and What It Means to Be Human, New York: Broadway.

Geach, P. T. (1973). Omnipotence. Philosophy 48 (183), 7-20.

Geisler, N.L (1992). Battle for the Resurrection. Nashville: Thomas Nelson.

Geivett, R.D. \& G.R. Habermas (1997). (eds.), In Defence of Miracles, Downers Grove, IL: InterVarsity.

Geraci, R. (2010). Apocalyptic AI: Visions of Heaven in Robotics, Artificial Intelligence, and Virtual Reality. New York: Oxford University Press.

Gervais, K. (1986). Redefining Death, New Haven, CT: Yale University Press.

González, J.L. (1984). The Story of Christianity, 1, Peabody: Prince Press.

Gordijn, B. \& R.F. Chadwick (2009). Medical Enhancement and Posthumanity. Dordrecht: Springer. 
Gray, C.H. (2001). Cyborg Citizen: Politics in the Posthuman Age. New York: Routledge.

Green, R. (2008). Babies by Design: The Ethics of Genetic Choice, New Haven CT.

Gregg, R.C. \& Groh, D.E. (1981). Early Arianism: A view of Salvation. Philadelphia: Fortress Press.

Grudem, W. (1994). Systematic Theology. Grand Rapids: Zondervan.

Gunter, W.S. (1999) Resurrection Knowledge: Recovering the Gospel for a Postmodern Church. Nashville: Abingdon.

Gwatkin, H. (1912). Early Church History to AD 313, London: Macmillan.

Gwatkin, H.M. (1898). The Arian Controversy. London: Longmans, Green and Co.

Habermas, G.R (2003). The Risen Jesus and Future Hope. Lanham, MD: Rowman \& Littlefield.

Habermas, G.R. (2004). The Case for the Resurrection of Jesus. 4th ed. Grand Rapids: Kregel.

Habermas, G.R., A.G.N. Flew, \& J.F. Ankerberg (2005). Resurrected? An Atheist and Theist Dialogue. Lanham, MD: Rowman \& Littlefield.

Halberstam, J. \& Livingston, I. (1995). (eds). Posthuman Bodies. Bloomington IN: Indiana University Press.

Halevy A. (2001). Beyond brain death? Journal of Medical Philosophy 11, 493-501.

Halevy, A. \& B. Brody (1993). Brain Death: Reconciling Definitions, Criteria, and Tests, Annals of Internal Medicine, 119: 519-25.

Halevy, A. (2001). Beyond Brain Death? Journal of Medicine and Philosophy, 26: 493-501.

Hall, S.S. (2003). Merchants of Immortality: Chasing the Dream of Human Life Extension. New York: Houghton Mifflin.

Hamilton, J. \& Hamilton B. (1998). Christian Dualist Heresies in the Byzantine World, c. 650-c. 1450: Selected Sources Translated and Annotated, Manchester: Manchester University Press 1998. 
Hansell, G.R. \& Grassie, W. (2011). (eds.) H+/-: Transhumanism and Its Critics. Philadelphia: Metanexus Institute.

Hanson, R. (1994). If Uploads Come First: The crack of a future dawn, Extropy 6, 2.

Hanson, R.P.C. (2005). The Search for the Christian Doctrine of God: The Arian

Controversy, 318-381. Grand Rapids: MI, Baker Publishing Group.

Harris, J. (2007). Enhancing Evolution: The Ethical Case for Making Better People. Princeton, NJ: Princeton University Press.

Harvard Medical School (1968). Ad Hoc Committee of the Harvard Medical School, “A Definition of Irreversible Coma: Report of the Ad Hoc Committee of the Harvard Medical School to Examine the Definition of Brain Death,” Journal of the American Medical Association 205 (6): 337-40.

Haughey, J.C. \& I. Delio (2014). Humanity on the Threshold: Religious Perspectives on Transhumanism. Washington, DC: Council for Research in Values \& Philosophy.

Hauskeller, M. (2013). Better Humans? Understanding the Enhancement Project. Durham, UK: Acumen Pub. Ltd.

Hauskeller, M., T.D. Philbeck \& C.D. Carbonell (2015). (eds.), The Palgrave Handbook of Posthumanism in Film and Television. New York: Palgrave Macmillan.

Hayles, N.K. (1999). How We Became Posthuman: Virtual Bodies in Cybernetics, Literature, and Informatics. Chicago: University of Chicago Press.

Hedrick C.W. \& R. Hodgson (1986). (ed.), Nag Hammadi Gnosticism and Early Christianity, Peabody, Mass.: Hendrickson Publishers.

Herbrechter, S. (2013). Posthumanism: A Critical Analysis. New York: Bloomsbury Academic.

Hodge, C. (1986). Systematic Theology. Grand Rapids: Eerdermans.

Hody, H. (1694). The Resurrection of the (Same) Body Asserted: From the traditions of the heathens, the ancient Jews, and the primitive Church. Oxford: University of Oxford Text Archive http://tei.it.ox.ac.uk/tcp/Texts-HTML/free/A44/A44092.html Retrieved 17 May 2017

Hoeller, S.A. (2002). Gnosticism: New Light on the Ancient Tradition of Inner Knowing, Quest Books

Holdsworth, W. (1727). A Defence of the Doctrine of the Resurrection of the Same Body, London: Charles Rivington 
Holroyd, S. (1994). The Elements of Gnosticism, Rockport, MA: Element Books.

Hoover, A.J. (1976). The Case for Christian Theism: An Introduction to Apologetics, Grand Rapids: Baker.

Hughes, J. (2004). Citizen Cyborg: Why Democratic Societies must Respond to the Redesigned Human of the Future. NY: Basic Books.

Hulsroj, P. (2015). What if We Don't Die? The Morality of Immortality. New York: Springer.

Hunter, I., Laursen, J.C. \& Nederman, C.J. (2005). (eds.), Heresy in Transition:

Transforming Ideas of Heresy in Medieval and Early Modern Europe, Aldershot: Ashgate.

Hyde, M.J. \& Herrick, J.A. (2013). (eds.) After the Genome: The Language of our Biotechnology Future. Waco TX: Baylor University Press.

Hyde, M.J. (2010). Perfection: Coming to Terms with Being Human. Waco TX: Baylor University Press.

Iltis A.S. \& Cherry M.J. (2010). Death revisited: rethinking death and the dead donor rule. Journal of Medicine and Philosophy. 35(3):223-41.

Iricinschi, E \& Zellentin, H.M. (2008). (eds.), Heresy and Identity in Late Antiquity, Tübingen: Mohr Siebeck.

Jolley, N. (2015). Locke’s Touchy Subjects: Materialism and Immortality, Oxford: OUP.

Johnson, D.W. (2005). The Great Jesus Debates: 4 Early Church Battles about the Person and Work of Jesus. Saint Louis: MO Concordia Publishing House.

Julian, S. \& N. Bostrom (2009). Human Enhancement. New York: Oxford University Press.

Kass, L. (2004). Life, Liberty, and the Defense of Dignity: The Challenge for Bioethics. New York: Encounter Books.

Kelly, J.F. (2012). History and Heresy: How Historical Forces Can Create Doctrinal Conflicts, Collegeville: Liturgical Press.

Kelly, J.F. (2009). The Ecumenical Councils of the Catholic Church: A History,

Collegeville, Minnesota: Liturgical Press.

Kelly, J.N.D (1978). Early Christian Doctrine, San Francisco: HarperCollins. 
Kelly, J.N.D (1981). Early Christian Creeds, Harlow: Addison-Wesley Longman Limited.

King, K.L. (2003). What is Gnosticism? Harvard University Press.

King-Tak, Ip. (2009). Bioethics of Regenerative Medicine. New York: Springer.

Koosed, J.L. (2014). (ed.), The Bible and Posthumanism. Atlanta: Society of Biblical Literature.

Kreeft, P. \& R.K Tacelli (1994). Handbook of Christian apologetics. Downers Grove, IL: InterVarsity

Kreeft, P. (1983). Between Heaven and Hell. Downers Grove, IL: InterVarsity

Kuramochi T. (2005). Reconsidering the dead donor rule. Journal International de Bioéthique 16(12):117-22, 196-7.

Kurzweil, R. (2000). The Age of Spiritual Machines: When Computers Exceed Human Intelligence, NY: Penguin.

Kurzweil, R. (2006). The Singularity is Near: When Humans Transcend Biology. NY: Penguin.

Kurzweil, R. (2013). How to Create a Mind: The Secret of Human Thought Revealed. New York: Penguin.

Ladd, G.E. (1975). I Believe in the Resurrection of Jesus. Grand Rapids: Eerdemans.

Lake, C.B., (2013). Prophets of the Posthuman: American Fiction, Biotechnology, and the Ethics of Personhood. Notre Dame IN: University of Notre Dame Press.

Landes, R.A. (2002). The Birth of Heresy: A Millennial Phenomenon, Journal of Religious History 24 (1), 26-43.

Laursen, J.C. (2002). (ed.), Histories of Heresy in Early Modern Europe: For, Against, and Beyond Persecution and Toleration, New York: Palgrave.

Laux, J.L. (1989). Church History, Rockford, Illinois: Tan Books \& Publishers.

Layton, B. (1981). (ed.) The Rediscovery of Gnosticism. Leiden: Brill.

Layton, B. (1987). Gnostic Scriptures. Garden City: Doubleday.

Leon-Dufour, X. (1974). Resurrection and the Message of Easter. New York: Rinehart \& Winston. 
Levenson, J.D. (2006). Resurrection and the Restoration of Israel: The Ultimate Victory of the God of Life. New Haven: Yale University Press.

Levy, D. (2008). Love and Sex with Robots: The Evolution of Human-Robot Relationships. Harper Perennial.

Lewis, C.S. (1996). The Problem of Pain. New York: Simon \& Schuster.

Lewis, C.S. (2001). The Abolition of Man. New York: HarperCollins.

Liberal Democracies. Boston MA: MIT Press.

L'Huillier, P. (1996). The Church of the Ancient Councils: The Disciplinary Work of the First Four Ecumenical Councils, Crestwood: St Vladimir's Seminary Press.

Licona, M.R. (2010). The Resurrection of Jesus: A New Historiographical Approach. Downers Grove, IL: InterVarsity Press.

Lilley, S. (2012). Transhumanism and Society: The Social Debate over Human Enhancement. New York: Springer.

Linko K., Honkavaara P., Salmenperä M. (1982). Recovery after discontinued cardiopulmonary resuscitation. Lancet 1, 106-107.

LiPuma S1, DeMarco JP. (2014). A functionalist view of brain death. The American Journal of Bioethics 14(8):19-20.

Lizza, J. (2007). Persons, Humanity, and the Definition of Death, Baltimore, MD: Johns Hopkins University Press.

Lo, V. (2012). (ed.), Perfect Bodies: Sports, Medicine, and Immortality Ancient and Modern. Lond: British Museum Press.

Locke, J. \& J. W. Yolton (1977). The Locke Reader: Selections from the Works of John Locke with a General Introduction and Commentary, Cambridge: CUP

Locke, J. (1961). An Essay Concerning Human Understanding, ed. J.W. Yolton, London: Dent.

Lolordo, A. (2010). Person, Substance, Mode and 'the moral Man’ in Locke's Philosophy, Canadian Journal of Philosophy, 40 (4); 643-668.

LoLordo, A. (2012). Locke’s Moral Man, Oxford: OUP. 
Loos, M. (1974). Dualist Heresy in the Middle Ages, Praha: Academia.

Lourdaux, W. \& Verhelst, D. (1973). (eds.), The Concept of Heresy in the Middle Ages (11th-13th C.), Leuven: Leuven University Press.

Luce, A.A. (1920). Monophysitism Past and Present: A Study in Christology, New York: Macmillan Pages.

Lüdemann, G. (1996). What Really Happened to Jesus: A Historical Approach to the Resurrection, Louisville: Westminster John Knox.

MacMullen, R. (2006). Voting About God in Early Church Councils, New Haven: Yale University Press.

Magnus, D, A. Caplan \& G. McGee (2002). (eds.), Who Owns Life? Amherst NY: Prometheus.

Magnus, D.C., B.S. Wilfond, \& A.L. Caplan (2014). Accepting Brain Death, New England Journal of Medicine, 370: 891-894.

Margull, H.J. (1966). (ed.), The Councils of the Church, Philadelphia: Fortress Press.

Marshall, J. (2000). Locke Socinianism Socinianism and Unitarianism, in: Stewart, M.A. (ed.) English Philosophy in the Age of Locke, Clarendon Press., 111-182.

Martin, E.J. (1978 [1930]). A History of the Iconoclastic Controversy, New York: AMS Press.

Mattern, R. (1980). Moral Science and the Concept of Persons in Locke, The Philosophical Review, 89(1): 24-45.

Mavrodes, G. (19780. Some Puzzles Concerning Omnipotence, in: Urban, L. \& D. Walton (eds.) The Power of God: Readings on Omnipotence and Evil, Oxford: Oxford University Press, $144-52$.

McCane, B.R. (2003). Roll Back the Stone: Death and Burial in the World of Jesus. Harrisburg, PA: Trinity Press International.

McDonald, J.I.H. (1989). The Resurrection Narrative and Belief. London: SPCK.

McDonald, L.M. \& Sanders J.A. (2002) (eds.), The Canon Debate, Peabody: Hendrickson Publishers.

McGrath, A. (2009). Heresy: A History of Defending the Truth, London: SPCK. 
McKenna, M. (2004). And Morning Came: Scriptures of the Resurrection. Lanham, MD: Sheed \& Ward.

McMahan, J. (2006). An Alternative to Brain Death, Journal of Law, Medicine, and Ethics, 34: 4448.

Mehlman, M.J. (2009). The Price of Perfection: Individualism and Society in the Era of Biomedical Enhancement. Baltimore MD: Johns Hopkins University Press.

Mehlman, M.J. (2012). Transhumanist Dreams and Dystopian Nightmares: The Promise and Peril of Genetic Engineering. Baltimore MD: Johns Hopkins University Press.

Mercer, C \& Maher, D. (2014). (eds.), Transhumanism and the Body: The World Religions Speak. New York: Palgrave Macmillan.

Mercer, C. \& Trothen, T. (2014). (eds.), Religion and transhumanism: the unknown future of human enhancement. Westport, CT: Praeger.

Mercer, C. and D.F. Maher (2014). (eds.), Religion and the Implications of Radical Life Extension. New York: Palgrave Macmillan.

Merkle, R (1992). The technical feasibility of cryonics. Medical Hypotheses. 39 (1): 6-16.

Merrell, F. (2003). Sensing Corporeally: Toward a Posthuman Understanding: Toronto: University of Toronto Press.

Miccoli, A. (2010). Posthuman Suffering and the Technological Embrace. Lanham, MD: Lexington Books.

Miller, F.G. \& R. D. Truog (2010). Decapitation and the Definition of Death, Journal of Medical Ethics, 36, 1-6.

Miller, F.G., Truog, R.D. (2009). The incoherence of determining death by neurological criteria: a commentary on 'Controversies in the determination of death", Kennedy Institute of Ethics Journal, 19(2), 185-93.

Mitchell, C.B., R.D. Orr \& S.A. Salladay (2004). (eds), Aging, Death, and the Quest for Immortality. Grand Rapids: Eerdmans.

Molloy, C. \& S. Shakespeare. (2012). Beyond Human: From Animality to Transhumanism. New York: Continuum.

Moore, P. (2008). Enhancing Me: The Hope and the Hype of Human Enhancement. West Sussex, England: John Wiley \& Sons Ltd. 
Moore, R.I. (1970). The Origins of Medieval Heresy, History: The Quarterly Journal of the Historical Association 55, 21-36.

Moore, R.I. (1994). The Origins of European Dissent, Toronto: University of Toronto Press.

Moore, R.I. (2000). The Birth of Popular Heresy: A Millennial Phenomenon? Journal of Religious History 24, 8-25.

Moore, R.I. (2008). The War against Heresy in Medieval Europe, Historical Research 81, 189-210.

Moravec, H. (1990). Mind Children: The Future of Robot and Human Intelligence. Cambridge MA: Harvard University Press.

Moravec, H. (2000). Robot: Mere Machine to Transcendent Mind. Oxford UK: Oxford University Press.

More, M. \& Vita-More, N. (2013). (eds.), The transhumanist Reader: classical and contemporary essays on the science, technology, and philosophy of the human future. Hoboken, N.J.: Wiley.

Moreland, J.P. (1987). Scaling the Secular City, Grand Rapids: Baker.

Murphy, J.L (1960). The General Councils of the Church, Milwaukee: The Bruce Publishing Company.

Naam, R. (2005). More than Human: Embracing the Promise of Biological

Nayar, P.K. (2014). Posthumanism. Malden, MA: Polity.

Nietzsche, F. (1973 [1885]). Thus Spoke Zarathustra trans. R. J. Hollingdale, New York: Penguin.

Nietzsche, F. (1974 [1887]). The Gay Science trans. Walter Kaufman, New York: Vintage.

Nimbalkar N., (2011). John Locke on Personal Identity. Mens Sana Monographs, 9(1), $268-275$.

Noble, T.F.X. \& J.M.H. Smith (2008). (eds.), The Cambridge History of Christianity III: Early Medieval Christianities c. 600-c. 1100, Cambridge: Cambridge University Press.

Noll, M.A. (2000). Turning Points: Decisive Moments in the History of Christianity. Grand Rapids, MI: Baker Academic. 
Nourbakhsh, I.R. (2013). Robot Futures. Boston MA: MIT Press.

O’Collins, G. (1987). Jesus Risen: Resurrection-What Actually Happened and What Does It Mean? New York: Paulist Press.

O’Collins, G. (1993). The Resurrection of Jesus Christ: Some Contemporary Issues. Milwaukee: Marquette University Press.

Ogliari, D. (2003). Gratia et certamen: The Relationship between Grace and Free Will in the Discussion of Augustine with the So-Called Semipelagians, Leuven: Leuven University Press.

Olshansky, S.J. \& B.A. Carnes. (2001). The Quest for Immortality: Science at the Frontiers of Aging: New York: Norton.

Ott, L. (1974). Fundamentals of Catholic Dogma. Rockford, IL: Tan Books.

Pagels, E. (1978). The Gnostic Gospels, New York: Random House.

Pallis, C. (1983). The ABC of Brain Death, London: British Medical Journal Publishers.

Pallis, C. (1999). On the Brainstem Criterion of Death, in: S. Youngner, R. Arnold, and R. Shapiro (eds.), The Definition of Death: Contemporary Controversies, Baltimore, MD: Johns Hopkins University Press, 93-100.

Palmer, E.H. (1999). The five points of Calvinism, Baker Books.

Parens, E. (1998). (ed.), Enhancing Human Traits. Washington, DC: Georgetown University Press.

Parens, E. (2006). (ed.) Surgically Shaping Children: Technology, Ethics, and the Pursuit of Normality. Baltimore: Johns Hopkins University Press.

Parvis, S. (2006). Marcellus of Ancyra and the Lost Years of the Arian Controversy, Oxford: Oxford University Press.

Patrides, A. (1958). Renaissance and modern thought on the last things: a study in changing conceptions, Harvard Theological Review, 51, 179-180.

Paul, G.S., \& E.D. Cox (1996). Beyond Humanity: Cyberevolution and Future Minds. Rockland MA: Charles River Media.

Pearson, J. (1676). An Exposition of the Creed, London: J.M. for John Williams. 
Pegg, M.G. (2008). A Most Holy War: The Albigensian Crusade and the Battle for Christendom, Oxford: Oxford University Press.

Pelikan, J. (1971-1989). The Christian Tradition: A History of the Development of Doctrine. 5 vols. Chicago: University of Chicago Press.

Pence, G.E. (2012). How to Build a Better Human: An Ethical Blueprint. New York: Rowman \& Littlefield Publishers.

Pepperell, R. (2009). The Posthuman Condition: Consciousness beyond the Brain. Portland OR: Intellect.

Perkins, P. (1980). The Gnostic Dialogue. New York: Paulist.

Perkins, P. (1981). Gnostic Christologies and the New Testament. CBQ 43, 590-606.

Pernick, M. (1999). Brain Death in a Cultural Context: The Reconstruction of Death, 1967-1981, in: S. Youngner, R. Arnold, \& R. Shapiro (eds.), The Definition of Death: Contemporary Controversies, Baltimore, MD: Johns Hopkins University Press, 3-33.

Perry, J.M. (1993). Exploring the Resurrection of Jesus. Chicago: Sheed \& Ward.

Persson, I. (2002). Human Death: A View from the Beginning of Life, Bioethics, 16: 20-32.

Peters, E. (1980). (ed.), Heresy and Authority in Medieval Europe: Documents in Translation, London: Scolar Press.

Peters, T., R.J. Russell \& M. Welker (2002). (eds.), Resurrection: Theological and Scientific Assessments. Grand Rapids: Eerdmans.

Pink, A.W. (1984). The Sovereignty of God, Baker Book House.

Potts, M. (2001). A Requiem for Whole Brain Death, Journal of Medicine and Philosophy, 26, 47992.

Potts, M., P.A. Byrne \& R.G. Nilges (2001). Beyond Brain Death: The Case Against Brain Based Criteria for Human Death, Springer

Price, R.M. \& J.J. Lowder (2005). (eds.) The Empty Tomb: Jesus beyond the Grave. Amherst, NY: Prometheus.

Puccetti, R. (1988). Does Anyone Survive Neocortical Death, in: R. Zaner (ed.), Death: Beyond Whole-Brain Criteria, Dordrecht, Netherlands: Kluwer: 75-90. 
Rady, M.Y \& Verheijde J.L. (2013). Brain-dead patients are not cadavers: the need to revise the definition of death in Muslim communities. HEC Forum, 25(1), 25-45.

Ranisch, R \& Sorgner, S.L (2014). (eds.), Post- and Transhumanism. Bruxelles: Peter Lang.

Rees, B. R. (1988). Pelagius: A Reluctant Heretic, Woodbridge: The Boydell Press.

Rees, BR. (1988b). Pelagius: Life and Letters, Woodbridge: The Boydell Press.

Regis, E. (1990). Great Mambo Chicken and the Transhuman Condition, New York: Perseus.

Rich, B., 1997, “Postmodern Personhood: A Matter of Consciousness,” Bioethics, 11: 206-16.

Roach, A.P. \& J.R. Simpson (2013). (eds.), Heresy and the Making of European Culture: Medieval and Modern Perspectives, Burlington: Ashgate.

Roach, A.P. (2005). The Devil's World: Heresy and Society, 1100-1300, Harlow:

Pearson.

Robinson, J.M. (1988). (ed.), The Nag Hammadi Library in English. San Francisco: Harper \& Row.

Ross, A. (1645). Medicus medicates: Or the physician's religion cured, by a lenitive or gentle potion with some animadversions upon Sir Kenelme Digby's observations on Religio medici

Rothman, S. \& D. Rothman (2003). The Pursuit of Perfection: The Promise and Perils of Medical Enhancement. New York: Pantheon Books.

Rubin, M \& Simons, W. (2009). (eds.), The Cambridge History of Christianity IV:

Christianity in Western Europe c. 1100-c. 1500, Cambridge: Cambridge University Press.

Rudolph, K. (1983). Gnosis: The Nature and History of Gnosticism, San Francisco: Harper \& Row.

Russell, J.B. (1963). Interpretations of the Origins of Medieval Heresy, Mediaeval Studies $25,26-53$.

Russell, J.B. (1971). (ed.), Religious Dissent in the Middle Ages, London: John Wiley and Sons.

Russell, J.B. (1992). Dissent and Order in the Middle Ages: The Search for Legitimate Authority, New York: Twayne. 
Sackville, L.J. (2011). Heresy and Heretics in the Thirteenth Century: The Textual Representations, York: York Medieval Press.

Sade, R.M. \& Boan, A. (2014). The paradox of the dead donor rule: increasing death on the waiting list. The American Journal of Bioethics, 14(8):21-3.

Sade, R.M. (2011). Brain Death, Cardiac Death, and the Dead Donor Rule, Journal of the South Carolina Medical Association, 107, 146-149.

Sade, R.M. (2014). Consequences of the Dead Donor Rule. The Annals of Thoracic Surgery. 97(4):1131-2.

Sadovnikoff N. \& Wikler D. (2014). Brain dead patients are still whole organisms. The American Journal of Bioethics, 14(8):39-40.

Sandel, M. (2009). The Case against Perfection: Ethics in the Age of Genetic Engineering: Cambridge MA: Belknap Press of Harvard University.

Savulescu, J. \& N. Bostrom (2009). (eds.), Human Enhancement. New York: Oxford University Press.

Savulescu, J., R.H.J. ter Meulen, \& G. Kahane (2011). Enhancing Human Capacities. Chichester, West Sussex, UK: Wiley-Blackwell.

Schaff, P. \& Schaff, D.S. (1910). History of the Christian Church. 3. New York: C Scribner's Sons

Schlier, H. (2008). On the Resurrection of Jesus Christ. Rome: 30Giorni.

Scott, B.B. (2008). (ed.), The Resurrection of Jesus: A Sourcebook. JSG 4. Santa Rosa, CA: Polebridge.

Scott, B.B. (2010). The Trouble with Resurrection: From Paul to the Fourth Gospel. Salem, OR: Polebridge.

Scott, P.M. (2010). Anti-Human Theology: Nature, Technology and the Post-Natural. Baltimore: Johns Hopkins University Press.

Seidel, A. (2008). Inhuman Thoughts: Philosophical Explorations of Posthumanity. Lanham MD: Lexington Books.

Seidel, A. (2010). Immortal Passage: Philosophical Speculations on Posthuman Evolution. Lanham, MD: Lexington Books. 
Shapiro (eds.), The Definition of Death: Contemporary Controversies, Baltimore, MD: Johns Hopkins University Press, 71-82.

Sharon, T. (2013). Human Nature in an Age of Biotechnology: The Case for Mediated Posthumanism. New York: Springer.

Shaw, S., R.D. Truog \& F.G. Miller (2011). Death and Legal Fictions, Journal of Medical Ethics, 37, 719-722.

Shewmon, D.A. (1998). Chronic ‘Brain Death’: Meta-Analysis and Conceptual Consequences,” Neurology 51,1538-45.

Shewmon, D.A. (2001). The brain and somatic integration: insights into the standard biological rationale for equating 'brain death' with death. Journal of Medicine and Philosophy, 11, 457-478.

Shewmon, D.A. (2001). The Brain and Somatic Integration: Insights into the Standard Biological Rationale for Equating 'Brain Death' with Death, Journal of Medicine and Philosophy, 26, 457-78.

Shostak, S. (2002). Becoming Immortal: Combining Cloning and Stem Cell Therapy. New York: SUNY Press.

Shuldrick, M. \& R. Mykitiuk. (2005). Ethics of the Body: Postconventional Challenges. Cambridge, MA: MIT Press.

Siminoff L.A, Burant C. \&Youngner S.J. (2004). Death and organ procurement: public beliefs and attitudes. Kennedy Institute of Ethics Journal, 14(3), 217-34.

Slone, J.D. (2004). Theological Incorrectness: Why Religious People Believe What They Shouldn't, Oxford: Oxford University Press 2004.

Smith, D.A. (2010). Revisiting the Empty Tomb: The Early History of Easter. Minneapolis: Fortress.

Stock, G. (2003). Redesigning Humans: Choosing our Genes, Changing our Future, Mariner.

Stoyanov, Y. (2000). The Other God: Dualist Religions from Antiquity to the Cathar Heresy, New Haven: Yale University Press.

Strawson, G. (2011) Locke on Personal Identity, Princeton, Princeton University Press.

Strobel, L. (2010). Case for Christ/Case for Faith Compilation, HarperCollins

Sweet WH. (1978). Brain death. New England Journal of Medicine, 11, 410-412. 
Swinburne, R. (2003). The Resurrection of God Incarnate. New York: Oxford University Press.

Tabbernee, W. (1997). (ed.) Montanist Inscriptions and Testimonia: Epigraphic Sources Illustrating the History of Montanism, Macon: Mercer University Press.

Tabbernee, W. (2007). Fake Prophecy and Polluted Sacraments: Ecclesiastical and Imperial Reactions to Montanism, Leiden: Brill.

Tanner, N.P. (1990). (ed.), Decrees of the Ecumenical Councils. New York: Sheed \& Ward.

Tanner, N.P (2001). The Councils of the Church, New York: Crossroad.

Tenney, M.C. (1963). The Reality of the Resurrection. New York: Harper \& Row.

Thomas, A.G. (2012). Continuing the Definition of Death Debate: The Report of the President's Council on Bioethics on Controversies in the Determination of Death, Bioethics, 26, 101-107.

Thweatt-Bates, J. (2012). Cyborg Selves: A Theological Anthropology of the Posthuman, UK: Ashgate.

Tillotson, J. (1682). The possibility of the resurrection asserted and proved, in: Works, 3 vols. London: 1728), iii. 248-55.

Tipler, F.J. (1994). The Physics of Immortality, New York: Doubleday.

Truog, M.D. \& F.G. Miller (2012). Death, Dying, and Organ Transplantation: Reconstructing Medical Ethics at the End of Life, New York: Oxford University Press.

Truog, M.D. (2008). The Dead Donor Rule and Organ Transplantation, New England Journal of Medicine, 359, 674-675.

Truog, R.D. \& Miller F.G. (2008). The dead donor rule and organ transplantation. 359(7):674-5. New England Journal of Medicine, 359(7):674-5.

Truog, R.D. \& W.M. Robinson (2003). Role of Brain Death and the Dead-Donor Rule in the Ethics of Organ Transplantation, Critical Care Medicine, 31, 2391-2396.

Urban, L. \& D. Walton (1978). (eds.) The Power of God: Readings on Omnipotence and Evil, Oxford: Oxford University Press. 
Uzgalis, W. (1988). “The Anti-Essential Locke and Natural Kinds”, The Philosophical Quarterly, 38(152): 330-339.

Uzgalis, W. (1990). Relative Identity and Locke's Principle of Individuation, History of Philosophy Quarterly, 7(3): 283-297.

Uzgalis, W. (2007). Locke's Essay Concerning Human Understanding: A Reader's Guide, Continuum.

Veatch R.M (2004). Abandon the dead donor rule or change the definition of death? Kennedy Institute of Ethics Journal. 14(3), 261-76.

Veatch, R. (1975). The Whole-Brain-Oriented Concept of Death: An Outmoded Philosophical Formulation, Journal of Thanatology, 3: 13-30.

Veatch, R. (1976). Death, Dying, and the Biological Revolution, New Haven, CT: Yale University Press.

Veatch, R. (1993). The Impending Collapse of the Whole-Brain Definition of Death, Hastings Center Report, 23 (4): 18-24.

Vermes, G. (2008). The Resurrection: History and Myth. New York: Doubleday.

Wade, S.C. (1967). The Paradox of the Stone. Philosophical Review 76 (1), 74-79.

Wakefield, W.L. \& Evans, A.P. (1991). Heresies of the High Middle Ages: Selected Sources Translated and Annotated, New York: Columbia University Press.

Waterman, M.W. (2006). The Empty Tomb Tradition of Mark: Text, History, and Theological Struggles. Los Angeles: Agathos.

Waters, B. (2006). From Human to Posthuman: Christian Theology and Technology in a Postmodern World. Burlington VT: Ashgate.

Waters, B. (2014). Christian Moral Theology in the Emerging Technoculture: From Posthuman Back to Human. Burlington, VT: Ashgate.

Waugh, S.L. \& P.D. Diehl (1996). (eds.), Christendom and its Discontents: Exclusion, Persecution, and Rebellion, 1000-1500, Cambridge: Cambridge University Press.

Weaver, R.H. (1996). Divine Grace and Human Agency: A Study of the Semi-Pelagian Controversy, Macon: Mercer University Press. 
Weiner, J. (2001). Long for this World: The Strange Science of Immortality, Ecco/Harper Collins.

Wenham, J. (1993). Easter Enigma: Do the Resurrection Accounts Contradict one Another? Grand Rapids: Baker.

Westcott, B.F. (1902). The Gospel of the Resurrection: Thoughts on Its Relation to Reason and History. London: Macmillan.

Whetstine, L. (2006). An examination of the biophilosophical literature on the definition and criteria of death: when is dead dead and why some donation after cardiac death donors are not, PhD Dissertation, Duquesne University.

Whetstine, L., Streat, S., Darwin, M., Crippen, D. (2005). Pro/con ethics debate: When is dead really dead? Critical Care. 9 (6): 538-542.

White, R. (2015). The Hidden God: Pragmatism and Posthumanism in American Thought. Columbia University Press.

Wierenga, E. (1983). Omnipotence Defined.

Wijdicks, E. (2002). Brain Death Worldwide: Accepted Fact But No Global Consensus on Diagnostic Criteria, Neurology, 58, 20-5.

Wiles, M. (1996). Archetypal Heresy: Arianism through the Centuries, Oxford: Oxford University Press.

Wilkins, M.J. \& Moreland, J.P. (1995). (eds.), Jesus Under Fire, Grand Rapids: Zondervan.

Williams, R. (2001). Arius: Heresy and Tradition, London: Darton Longman and Todd.

Williams, R. (2003). Resurrection: Interpreting the Easter Gospel. Cleveland: Pilgrim Press, 2003.

Wilson, R.M. (1968). Gnosis and the New Testament. Oxford: Oxford University Press.

Wilson, W. (1694). A Discourse of the Resurrection: Shewing the import and certainty of it, London: J.H for William Rogers.

Wink, W. (1993). Cracking the Gnostic Code: The Powers in Gnosticism. SBL Monograph Series 46. Atlanta: Scholars.

Wolfe, C. (2010). What Is Posthumanism? Minneapolis: University of Minnesota Press. 
Wood, D. (1993). (ed.), Martyrs and Martyrologies, Oxford: Blackwell 1993

Wright, N.T. (2003). The Resurrection of the Son of God, Fortress Press

Wright, N.T. (2003). The Resurrection of the Son of God. Christian Origins and the Question of God 3. Minneapolis: Fortress.

Wright, N.T. (2008). Surprised by Hope: Rethinking Heaven, the Resurrection, and the Mission of the Church. New York: HarperOne.

Yolton, J. (1956). John Locke and the Way of Ideas Oxford: Oxford University Press.

Yolton, J. (1969). John Locke: Problems and Perspectives, Cambridge: Cambridge University Press.

Yolton, J. (1970). John Locke and the Compass of Human Understanding, Cambridge: Cambridge University Press.

Yolton, J. (1984a). Perceptual Acquaintance: From Descartes to Reid, Minneapolis: University of Minnesota Press.

Yolton, J. (1984b). Thinking Matter: Materialism in Eighteenth Century Britain, Minneapolis: University of Minnesota Press.

Yolton, J. (1990). A Locke Miscellany, Bristol: Thommes Antiquarian Books.

Zaner, R.M. (1988). (ed.), Death: Beyond Whole-Brain Criteria, Dordrecht, the Netherlands: Kluwer.

Zito, G.V. (1983).Toward a Sociology of Heresy“, Sociological Analysis 44 (2), 123- 130. 